\title{
Sensitivity analysis and calibration of a soil carbon model (SoilGen2) in two contrasting loess forest soils
}

\author{
Y. Y. Yu' ${ }^{1}$, P. A. Finke ${ }^{2}$, H. B. Wu ${ }^{1}$, and Z. T. Guo ${ }^{1}$ \\ ${ }^{1}$ Key Laboratory of Cenozoic Geology and Environment, Institute of Geology and Geophysics, \\ Chinese Academy of Science, 100029, Beijing, China \\ ${ }^{2}$ Department of Geology and Soil Science, University of Ghent, Krijgslaan 281, 9000 Ghent, Belgium \\ Correspondence to: Y. Y. Yu (yyy@mail.iggcas.ac.cn) and P. A. Finke (peter.finke@ugent.be) \\ Received: 13 June 2012 - Published in Geosci. Model Dev. Discuss.: 16 July 2012 \\ Revised: 25 November 2012 - Accepted: 6 December 2012 - Published: 8 January 2013
}

\begin{abstract}
To accurately estimate past terrestrial carbon pools is the key to understanding the global carbon cycle and its relationship with the climate system. SoilGen2 is a useful tool to obtain aspects of soil properties (including carbon content) by simulating soil formation processes; thus it offers an opportunity for both past soil carbon pool reconstruction and future carbon pool prediction. In order to apply it to various environmental conditions, parameters related to carbon cycle process in SoilGen2 are calibrated based on six soil pedons from two typical loess deposition regions (Belgium and China). Sensitivity analysis using the Morris method shows that decomposition rate of humus $\left(k_{\mathrm{HUM}}\right)$, fraction of incoming plant material as leaf litter ( $\mathrm{fr}_{\text {ecto }}$ ) and decomposition rate of resistant plant material $\left(k_{\mathrm{RPM}}\right)$ are the three most sensitive parameters that would cause the greatest uncertainty in simulated change of soil organic carbon in both regions. According to the principle of minimizing the difference between simulated and measured organic carbon by comparing quality indices, the suited values of $k_{\mathrm{HUM}}$, frecto and $k_{\mathrm{RPM}}$ in the model are deduced step by step and validated for independent soil pedons. The difference of calibrated parameters between Belgium and China may be attributed to their different vegetation types and climate conditions. This calibrated model allows more accurate simulation of carbon change in the whole pedon and has potential for future modeling of carbon cycle over long timescales.
\end{abstract}

\section{Introduction}

The terrestrial ecosystem is one of the essential parts of the global carbon cycle. Significant variations of terrestrial carbon pool at geological timescales have played an important role in past atmospheric $\mathrm{CO}_{2}$ concentration change (Falkowski et al., 2000; Post et al., 1990). The soil carbon pool is much larger than the biotic pool (Lal, 2004) and accounts for about two-thirds of the terrestrial carbon pool. Thus quantitative estimation of the soil carbon pool is the key to revealing the mechanism of past terrestrial carbon cycle and narrows the uncertainties in the global carbon cycle inventory. However, because only parts of the carbon pool are preserved in sediments, past soil carbon pool reconstruction is difficult by direct measurement. Modeling approaches then become the potential option for accurate estimation.

Currently, with the development of soil carbon models, quantitative simulation of soil carbon storage has been widely done, but mostly focuses on modern processes and aims to predict future atmospheric $\mathrm{CO}_{2}$ concentration change (Coleman et al., 1997; Jensen et al., 1997; Kelly et al., 1997; Li et al., 1997). Changes of past soil carbon pools over long timescales have to account for changes in soil properties (e.g., particle size, $\mathrm{pH}$ ) due to soil formation processes, which are seldom included in existing soil carbon models (Finke, 2012; Finke and Hutson, 2008; Mermut et al., 2000). Information on past soil formation factors for different regions is unavailable (Finke, 2012; Sauer et al., 2012), and few models consider the effect of all soil formation factors (Jenny, 1961; e.g., climate, organisms, relief, parent material and time) in simulation of soil formation (Kirkby, 1977; 
Minasny and McBratney, 1999, 2001; Minasny et al., 2008; Parton et al., 1987; Salvador-Blanes et al., 2007).

SoilGen2, developed by Finke (Finke, 2012; Finke and Hutson, 2008), is a first attempt to reconstruct most aspects of soil evolution by taking all soil formation factors into account. The advantage of the model is that it simulates the organic and inorganic carbon cycle simultaneously and reveals the influences on carbon pool by other soil processes at long time scales. The model has been validated and applied in European soils developed over $15000 \mathrm{yr}$ from loess parent materials (Finke, 2012; Finke and Hutson, 2008), and the results show that clear sensitivity and plausible response of this model to the "climate", "organisms" and "relief" factors of soil formation exist. It also has been confirmed that reconstructions of realistic initial status of soil profiles (including carbon and other element contents) can be evaluated through simulating soil formation by SoilGen2 (Sauer et al., 2012). Therefore, the model offers an opportunity to reconstruct the past soil carbon cycle.

Because the verification and application of SoilGen2 is still at its preliminary stage, only parts of the soil processes included in the model have been calibrated (e.g., calcite leaching and clay migration) (Finke, 2012; Finke and Hutson, 2008). No calibration on parameters related to organic carbon (OC) cycle has been done yet. This work is necessary, and this activity should be preceded by an analysis of such a model to determine its most sensitive parameters (Skjemstad et al., 2004).

In this study, soil pedons from two typical loess deposition regions (Belgium and China) with distinct climate conditions are selected to calibrate OC cycle process in SoilGen2. Loess deposits have been continuously and widely deposited in Eurasia since $22 \mathrm{Myr}$ ago (Guo et al., 2002; Kukla, 1987; Liu, 1985). More than 400 paleosols were developed in the loess-soil sequences in China (Guo et al., 2002), and these provide the best record for reconstruction of past carbon cycle through modeling soil formation processes in future studies.

In summary, the objectives of this study are as follows: (1) to use sensitivity analysis to assess which parameters in SoilGen2 potentially cause the greatest uncertainty in calculated change in soil OC in Belgium and China; and (2) to do calibration and validation of the parameters related to OC cycle in Belgian and Chinese soil pedons. We focus on forest vegetation on loess soils in this study.

\section{Material and methods}

\subsection{Modeling soil carbon change with SoilGen2}

In essence, SoilGen2 is an extended solute transport model solving the Richards equation for unsaturated water flow and the convection-dispersion equation for solute transport. Additionally, heat flow is calculated to estimate soil

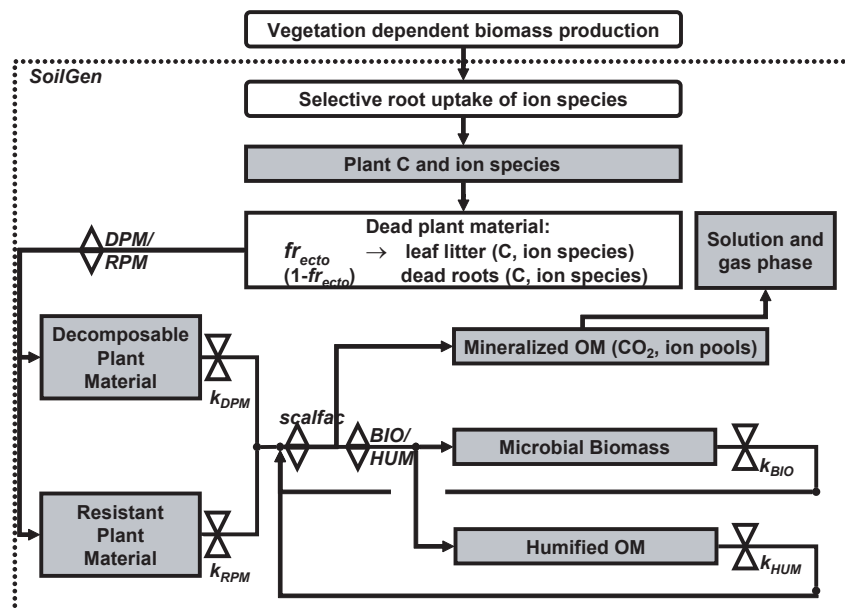

Fig. 1. Structure and process parameters of the organic C-module of SoilGen2. $\diamond$ indicates a distribution factor; $\stackrel{\nabla}{\Delta}$ is a rate factor. Process parameters are in italics; grey boxes indicate pools of $\mathrm{C}$ and associated ion species. The white square box is added for conceptualization, and white rounded boxes indicate processes. The dotted line indicates the model boundary.

temperature, which allows evaluation of the effect of soil temperature change on values of chemical constants, mineralization of OM (organic matter) and simulation of the effect of frozen soils on water flow. It simulates various aspects of pedogenesis including, e.g., OM accumulation, clay migration and $\mathrm{CaCO}_{3}$ leaching. For detailed model description, refer to Finke and Hutson (2008). This article focuses on the description of the OC cycle in SoilGen2, which interacts with other soil formation processes (e.g., clay migration, (de-)calcification and bioturbation) through the change of soil physical properties (porosity and texture), hydraulic and thermic conductivity, and associated water and heat flow in the soil profile. One clear feedback mechanism between soil formation processes and the OC-cycle is that changes in water content, clay content and temperature due to pedogenetic changes in soil properties affect the degradation rates of organic matter.

Basically, the soil profile is divided into a number of compartments with equal thickness, and the routines of SoilGen2 operate on every compartment separately. Therefore, changes of OC in the profile are modified by different water content, clay content and soil temperature in corresponding compartments. One key soil parameter for converting OC fractions to mass per unit area, bulk density, is calculated by the model by division between of the simulated mass of the solid phase and (fixed) volume per compartment.

Figure 1 shows the OC-cycle process modeled in SoilGen2. Vegetation provides dead plant material (leaf and root litter) as model input, which contains $\mathrm{Ca}^{2+}, \mathrm{Mg}^{2+}, \mathrm{K}^{+}, \mathrm{Na}^{+}$, $\mathrm{Al}^{3+}, \mathrm{Cl}^{-}, \mathrm{SO}_{4}^{2-}, \mathrm{HCO}_{3}^{-}$and $\mathrm{CO}_{3}^{2-}$ previously taken up from the soil solution via the transpiration stream. These 
ions follow the carbon decomposition pathway described hereunder dependent on vegetation types. Four vegetation types (grass/scrub, conifers, deciduous wood and agriculture/barley) are identified in SoilGen2, each having a unique root distribution pattern, associated water ion-uptake and target ion composition in living biomass (Finke, 2012: Table 2). Decomposition rates are considered invariant with respect to the various ion species, which is a simplification of the true system.

Dead plant material is distributed over root and leaf litter with a vegetation-dependent fraction $\mathrm{fr}_{\text {ecto }}$, and the root litter input is distributed over the soil depth such that it reflects the root density distribution. These litter inputs are then split and added to the decomposable (DPM) and resistant plant material (RPM) pools using the (vegetation-dependent) DPM/RPM factor. These plant material pools, existing in both the ectorganic layer and the individual mineral soil layers (endorganic layer), gradually decompose and mineralize while being incorporated and redistributed in the soil by bioturbation, which is modeled as an incomplete mixing process (Finke and Hutson, 2008). Each soil layer that is subject to bioturbation contributes a depth-dependent input mass fraction to a bioturbation pool, which is then mixed vertically.

Further decomposition of $\mathrm{OM}$ is modeled according to the concepts of the RothC26.3 model (Coleman and Jenkinson, 2005; Jenkinson and Coleman, 1994) using degradation rates that are modified as a function of soil temperature and moisture conditions. The mineralization process finally produces $\mathrm{CO}_{2}$ and releases cations and anions (Finke and Hutson, 2008: Fig. 1) into the soil solution. The decomposition rates of DPM, RPM, biomass (BIO) and humified OM (HUM) are considered similar for all vegetation types. This is also assumed for the scaling factor (scalfac) and the fractionation parameter $\mathrm{BIO} / \mathrm{HUM}$; scalfac is the constant (1.67) used in the equation to set the $\mathrm{CO}_{2} /(\mathrm{BIO}+\mathrm{HUM})$ ratio as in RothC 26.3 model, and the ratio is influenced by the clay content of the soil. In SoilGen2, the constant is transformed into a parameter that can be calibrated, and the ratio varies per soil compartment with the variation of clay content in the profile.

Figure 1 shows there are eight parameters that describe the carbon decomposition pathways: $\mathrm{fr}_{\text {ecto }}$, DPM/RPM (both for deciduous forest), $k_{\mathrm{DPM}}, k_{\mathrm{RPM}}$, scalfac, $\mathrm{BIO} / \mathrm{HUM}, k_{\mathrm{BIO}}$ and $k_{\text {HUM }}$. The relative importance of these parameters will be tested by sensitivity analysis and then calibrated in this study.

\subsection{Study regions}

\subsubsection{Belgian loess soil under permanent deciduous forest}

This study concerns soils at three topographic positions in the Sonian Forest near Brussels, Belgium $\left(50^{\circ} 46^{\prime} 31^{\prime \prime} \mathrm{N}\right.$, $4^{\circ} 24^{\prime} 9^{\prime \prime}$ E), developed in loess deposited during the Weichselian glaciation. The three pedons are located at mutual distances of less than $100 \mathrm{~m}$, but extensive research revealed a clear relation between slope exposition and decalcification depth (Langohr and Sanders, 1985), which was confirmed by model simulations (Finke, 2012). The loess cover is $2-4 \mathrm{~m}$ thick and overlies a dissected plateau of pre-Weichselian age in Tertiary clays that locally cause water stagnation, but not at the three plot sites. Langohr and Saunders (1985) proved that the landscape has hardly eroded in the last $20000 \mathrm{yr}$. Annals of landowners from the 14th century onwards indicate that this area was never under agriculture, as it was used for hunting by the nobility at least from this time onwards. Older reports indicate that it was a mixed beech/oak forest previously (Davis et al., 2003; Verbruggen et al., 1996). Currently, the area is under beech forest (Fagus Sylvatica) with selective felling activity. There is little undergrowth of blackberry (Rubus fruticosus). Detailed investigations also showed no evidence of plowing in the soil profiles (Van Ranst, 1981). Thus, soil development shows little human influence. The three pedons were classified as follows (IUSS Working Group WRB, 2006):

1. plateau position $(\mathrm{P})$ : stagnic cutanic fragic Albeluvisol (dystric, greyic, siltic);

2. south facing slope of $12^{\circ}(\mathrm{S})$ : cutanic fragic Albeluvisol (dystric, siltic);

3. north facing slope of $12^{\circ}(\mathrm{N})$ : cutanic fragic Albeluvisol (siltic).

Detailed analysis of the mineral soils of these pedons was reported in Finke (2012; Table 3). For this study, samples from the ectorganic litter layers were also taken and analyzed (Table 1) for later comparison with simulation results. Volume and dry weight were measured for bulk density estimation. The weight loss-on-ignition (LOI) method was used to determine OC. Because the Belgian soil has been decalcified and contains fairly low amounts of clay in the top, the bias of LOI method, overestimation of OC by ignoring loss of water from various clay minerals, calcite and gypsum, is negligible.

\subsubsection{Chinese loess soil under secondary and artificial deciduous forest}

This study also concerns three pedons at plateau position located in Ziwu Mountains (35-36 $\left.\mathrm{N}, 108-110^{\circ} \mathrm{E}\right)$, China, which is the best conserved region for secondary natural forests on the Loess Plateau. The pedons are developed in the loess deposited since Last Glacial Maximum (LGM). The soil depths are about 1-1.5 m, and it overlies the older loess deposited in Quaternary. Because the Loess Plateau is one of the important cultural origin and development centers in China, the vegetation in Ziwu Mountains has been disturbed by humans through felling and grazing activities in the Holocene (Liu, 2007). However, since 1870s population moved out of the region and in 1970s a forest 
Table 1. Selected analytical results of ectorganic and endorganic layers in Belgian and Chinese pedons. Results for endorganic layers of Belgian pedons were published in Finke (2012).

\begin{tabular}{|c|c|c|c|c|c|c|c|c|c|c|c|c|}
\hline \multicolumn{13}{|c|}{ Ectorganic layer } \\
\hline Region & \multicolumn{4}{|c|}{ Pedon } & \multicolumn{4}{|c|}{ Bulk density $\left(\mathrm{kg} \mathrm{dm}^{-3}\right)$} & \multicolumn{4}{|c|}{$\mathrm{OC}\left(\mathrm{Mg} \mathrm{ha}^{-1}\right)$} \\
\hline \multirow{4}{*}{ Belgium } & \multicolumn{4}{|c|}{ Plateau } & \multicolumn{4}{|c|}{0.090} & \multicolumn{4}{|c|}{15.372} \\
\hline & \multicolumn{4}{|c|}{ South facing slope } & \multicolumn{4}{|c|}{0.123} & \multicolumn{4}{|c|}{24.910} \\
\hline & \multicolumn{4}{|c|}{ North facing slope } & \multicolumn{4}{|c|}{0.146} & \multicolumn{4}{|c|}{27.142} \\
\hline & \multirow{2}{*}{\multicolumn{4}{|c|}{$\begin{array}{l}\text { LJB } \\
\text { ZW2 }\end{array}$}} & \multicolumn{4}{|c|}{0.243} & \multicolumn{4}{|c|}{15.432} \\
\hline \multirow[t]{2}{*}{ China } & & & & & \multirow{2}{*}{\multicolumn{4}{|c|}{$\begin{array}{l}0.220 \\
0.139\end{array}$}} & \multirow{2}{*}{\multicolumn{4}{|c|}{$\begin{array}{l}15.102 \\
12.095\end{array}$}} \\
\hline & \multicolumn{4}{|c|}{ ZW3 } & & & & & & & & \\
\hline \multicolumn{13}{|c|}{ Endorganic layer } \\
\hline Pedon & \multicolumn{4}{|c|}{ China LJB } & \multicolumn{4}{|c|}{ China ZW2 } & \multicolumn{4}{|c|}{ China ZW3 } \\
\hline Depth $(\mathrm{cm})$ & $\begin{array}{l}\mathrm{OC} \\
(\%)\end{array}$ & $\begin{array}{r}\text { Clay content } \\
(\%)\end{array}$ & $\mathrm{pH}$ & $\begin{array}{r}\mathrm{CaCO}_{3} \\
(\%)\end{array}$ & $\begin{array}{l}\mathrm{OC} \\
(\%)\end{array}$ & $\begin{array}{r}\text { Clay content } \\
(\%)\end{array}$ & $\mathrm{pH}$ & $\begin{array}{r}\mathrm{CaCO}_{3} \\
(\%)\end{array}$ & $\begin{array}{l}\mathrm{OC} \\
(\%)\end{array}$ & $\begin{array}{r}\text { Clay content } \\
(\%)\end{array}$ & $\mathrm{pH}$ & $\begin{array}{r}\mathrm{CaCO}_{3} \\
(\%)\end{array}$ \\
\hline $0-5$ & 5.058 & 10.205 & 8.030 & 6.391 & 1.819 & 11.333 & 8.080 & 6.001 & 2.434 & 11.482 & 8.310 & 13.358 \\
\hline $5-10$ & 4.310 & 10.656 & 8.220 & 6.984 & 1.888 & 9.024 & 8.110 & 6.568 & 3.004 & 9.000 & 8.250 & 13.023 \\
\hline $10-15$ & 2.643 & 9.897 & 8.110 & 8.279 & 2.140 & 9.123 & 8.070 & 6.520 & & & & \\
\hline $15-20$ & 1.594 & 10.641 & 8.600 & 10.018 & 2.015 & 8.433 & 8.270 & 6.182 & 1.752 & 9.069 & 8.230 & 13.324 \\
\hline $20-25$ & 1.360 & 9.078 & 8.460 & 11.447 & 1.831 & 10.844 & 8.300 & 5.479 & 103 & 0.580 & 8460 & 17642 \\
\hline $25-30$ & 1.340 & 10.715 & 8.660 & 11.801 & 1352 & 10450 & 8380 & 5501 & 1.193 & 9.509 & 0.400 & 11.042 \\
\hline $30-35$ & 0.959 & 10.316 & 8.550 & 12.321 & 1.352 & 10.459 & 8.380 & 5.501 & 0.550 & 10.081 & 8.460 & 17.703 \\
\hline $\begin{array}{l}35-40 \\
40-45\end{array}$ & 0.959 & 10.310 & & & 1.314 & 11.553 & 8.580 & 5.276 & & & & \\
\hline $45-50$ & 0.766 & 10.222 & 8.810 & 12.199 & & & & & 0.801 & 10.128 & 8.560 & 18.572 \\
\hline $50-55$ & & & & & 0927 & & & & & & & \\
\hline $\begin{array}{l}55-60 \\
60-65\end{array}$ & 0.521 & 11.078 & 8.760 & 13.128 & 0.921 & 11.818 & 8.680 & 1.909 & 0.679 & 9.566 & 8.490 & 19.121 \\
\hline $65-70$ & & & & & 0605 & 10945 & 8370 & 055 & & & & \\
\hline $70-75$ & & & & & 0.695 & 10.945 & $8.3 / 0$ & 0.955 & & & & \\
\hline $\begin{array}{l}75-80 \\
80-85\end{array}$ & 0.914 & 8.952 & 8.820 & 14.877 & 0.603 & 9.556 & 8.470 & 1.910 & 0.596 & 9.698 & 8.630 & 15.174 \\
\hline $\begin{array}{l}85-90 \\
85\end{array}$ & & & & & 0.475 & 9.260 & 8.450 & 9.814 & & & & \\
\hline $\begin{array}{l}90-95 \\
95-100\end{array}$ & 0.785 & 8.824 & 8.770 & 77.099 & & & & & 0.480 & 10.094 & 8.490 & 12.780 \\
\hline 100-105 & & & & & 0.498 & 10.490 & 8.530 & 13.981 & & & & \\
\hline $\begin{array}{l}105-110 \\
110-115\end{array}$ & & & & & & & & & & & & \\
\hline
\end{tabular}

protection project was started in this region by Chinese government. Currently, the area is covered with secondary natural forest (e.g., Quercus liaotungensis, Populus davidiana, Betula platyphylla) and production forest (e.g., Robinia). The three pedons are characterized as follows:

1. $\mathrm{LJB}\left(36^{\circ} 05^{\prime} \mathrm{N}, 108^{\circ} 34^{\prime} \mathrm{E}\right)$ slope of $0^{\circ}$ : calcic Luvisol (Gong et al., 2003; IUSS Working Group WRB, 2006), secondary natural forest (Populus davidiana, $25 \mathrm{yr}$ );

2. ZW2 $\left(35^{\circ} 26^{\prime} \mathrm{N}, 108^{\circ} 33^{\prime} \mathrm{E}\right)$ slope of $0^{\circ}$ : calcic Kastanozem (Gong et al., 2003; IUSS Working Group WRB, 2006), production forest (Robinia, $20 \mathrm{yr}$ );

3. ZW3 $\left(35^{\circ} 27^{\prime} \mathrm{N}, 108^{\circ} 38^{\prime} \mathrm{E}\right)$ slope of $0^{\circ}$ : calcic Kastanozem (Gong et al., 2003; IUSS Working Group WRB, 2006), production forest (Robinia, $20 \mathrm{yr}$ ).

Samples from ectorganic litter layers were taken in the same way as in the Sonian forest of Belgium, while in mineral layers samples were taken at $5-10 \mathrm{~cm}$ depth intervals. Bulk densities were measured by volume and dry weight method. The potassium dichromate method, which is not sensitive to the high $\mathrm{CaCO}_{3}$ content, is used for OC analysis (Table 1).

\subsection{Model input data}

Two types of inputs are included in SoilGen2: one is for boundary conditions (e.g., climate, litter input and bioturbation history); another is for initial conditions (e.g., soil properties, typical year weather pattern). A full simulation of soil from incipient stages of soil formation up to today (more than $10000 \mathrm{yr}$ ) is ideal, but it takes a long run time, which would render sensitivity analysis and calibration unfeasible. As former tests showed that amounts of OC in soil pedons would become stable after a 300-yr simulation in case of invariant climate and vegetation conditions (Finke and Hutson, 2008), all the tests in this study have a temporal extent of $1000 \mathrm{yr}$ so that effects of initial values of OC are eliminated and effects of soil properties are minimized. 


\subsubsection{Inputs for Belgium}

Climate and weather data were taken from the nearby weather station of Uccle (near Brussels and at $5 \mathrm{~km}$ from the studied site). A typical year of daily rainfall and weekly potential evapotranspiration data was used for the whole simulation period with an annual rainfall sum of $849 \mathrm{~mm}$ and potential evapotranspiration of $649 \mathrm{~mm}$. Over this year, the characteristics of precipitation (e.g., total amount of the rainfall, the number of days with rain, frequency of rainfall intensity and monthly distribution of rainfall) were similar to multi-year average conditions. The average January temperature was $3{ }^{\circ} \mathrm{C}$ and July temperature $18^{\circ} \mathrm{C}$. An annual litter input of $4.7 \mathrm{MgC} \mathrm{ha}^{-1} \mathrm{yr}^{-1}$ (A. Verstraeten, personal communication, Research Institute for Nature and Forest, Belgium, 2012) was taken. The bioturbation was assumed to be $8.2 \mathrm{Mg} \mathrm{ha}^{-1} \mathrm{yr}^{-1}$ affecting the upper $30 \mathrm{~cm}$ of soil (Gobat et al., 2004).

Initial physical and chemical properties of the soil pedons were only partly known from measurements (Finke, 2012: Table 3), and to obtain a complete set of initial soil properties we did the following:

1. Starting from the properties of the C-horizon, we simulated soil formation between $15000 \mathrm{yr}$ ago (end of loess deposition) to present. See Finke and Hutson (2008) and Finke (2012) for details concerning the modeling approach and inputs.

2. The simulated properties at present were taken as initial inputs for the various scenarios of following tests for the sensitivity analysis and calibration. However, simulated OC was re-initialized to $0.5 \%$ OC throughout the pedon.

As the Belgian climate is a strongly leaching one with practically no dust additions, above reconstruction reflects the effect of leaching on soil properties (e.g., soil texture, calcite and hydraulic properties) over $15000 \mathrm{yr}$ and shows a more realistic initial condition.

Comparison between simulations and measurements (Finke, 2012: Table 5) showed that simulations could reproduce the A-E-Bt horizon sequence and also the World Reference Base (WRB) soil classifications based on available (non-morphological) measurements. Therefore these simulations were considered as suitable basis for the current study.

\subsubsection{Inputs for China}

Representative climate data were interpolated from nearby weather stations in China. The average January/July temperatures were $-6 / 22^{\circ} \mathrm{C},-5 / 23^{\circ} \mathrm{C}$ and $-5 / 23^{\circ} \mathrm{C}$ for $\mathrm{LJB}$, $\mathrm{ZW} 2$ and ZW3, respectively, while annual rainfall and potential evapotranspiration were $482 / 1645 \mathrm{~mm}, 516 / 1582 \mathrm{~mm}$ and $519 / 1587 \mathrm{~mm}$, based on inverse distance interpolation of 30-yr (1958-1988) monitoring data of 61 weather stations distributed over the Loess Plateau. A typical year of daily rainfall and weekly potential evapotranspiration was from monitoring data of Xifeng in 1978 through comparing the characteristics of yearly precipitation at three weather stations near these soil pedons.

Annual input of litter (Populus $4.5 \mathrm{MgCha}^{-1} \mathrm{yr}^{-1}$, Robinia 4.4 $\mathrm{MgCha}^{-1} \mathrm{yr}^{-1}$ ) was transformed from measured biomass data (including volumes of growing stock per unit area, net annual increments and removals) in ZW forest station (Zhang and Shangguan, 2005), based on the protocol developed by De Wit et al. (2006). The bioturbation was assumed to be $15.3-17.4 \mathrm{Mg} \mathrm{ha}^{-1} \mathrm{yr}^{-1}$ affecting the upper 70 and $100 \mathrm{~cm}$ of soil for Populus and Robinia ecosystems, respectively (Gobat et al., 2004). In addition, distribution of monthly litter input and roots were adjusted in the model according to observed data of Populus and Robinia ecosystems in Loess Plateau (Cao et al., 2006; Cui et al., 2003; Hu et al., 2010; Zhang et al., 2001).

The Chinese climate has a large precipitation deficit, and redistributions of calcite and clay towards greater depths are not as significant as in Belgium. Furthermore, dust deposition is not negligible in study region of China, and fertilizes the profile with additional calcite and changes the particle size at the top. Soil properties with uncertain dust addition cannot be simulated accurately to reconstruct the situation of $1000 \mathrm{yr}$ ago, so we decided to assume that the current profile represents this situation fairly well, and initial physical and chemical properties of the soil pedons were from measurements of their parent material layers at the bottom of pedon (Table 1).

\subsubsection{Sensitivity analysis method}

Sensitivity analysis (SA) determines the response of selected model outputs to variations (within plausible bounds) of uncertain input parameters (Saltelli et al., 2000). Results of SA can be used to select and rank the most important parameters for calibration. Various SA methods have been developed (Saltelli et al., 2005). A choice of a particular method is based on a function of the number of parameters to be evaluated and the CPU-time per run. The number of parameters to be evaluated in the current study is eight, and a typical SoilGen-run for a 1000 -yr period takes about $20 \mathrm{~h}$ CPU time. Under these circumstances, Saltelli et al. (2005) proposed four methods: Bayesian sensitivity analysis (Oakley and O'Hagan, 2004), fractional factorial designs (Campolongo et al., 2000), automated differentiation techniques (Grievank and Walter, 2008) and the Morris method (Morris, 1991).

Bayesian sensitivity analysis is more efficient than traditional Monte Carlo techniques but still requires substantial amounts of simulations and reprogramming of the SoilGen code. This technique is therefore considered beyond the scope of this study. Fractional factorial designs have the disadvantage that assumptions need be made on model behavior. Automated differentiation techniques also require substantial 
reprogramming of the model code and may lead to results only representing local areas in parameter space (Saltelli et al., 2005). The Morris method is feasible in terms of computing time, because it takes samples from levels rather than from distributions of parameters (which may be a drawback when such distributions are known, but this is not the case here). For the above reasons we chose to apply the latter method.

The Morris method is based on the principle that one factor (model parameter) is varied at a time over a certain number of levels in parameter space. Each variation, comprising two simulations, leads to a so-called elementary effect $u_{i}$ :

$u_{i}=\frac{Y\left(x_{1}, x_{2}, \ldots, x_{i}+\Delta x_{i}, \ldots, x_{k}\right)-Y\left(x_{1}, x_{2}, \ldots, x_{i}, \ldots, x_{k}\right)}{\Delta x_{i}}$

where $x$ is the parameter value, $\Delta x_{i}$ its imposed variation for factor $i$ only ( $\Delta x_{i}=0$ for the other factors) and $Y(x)$ the model result with parameter set $x$. Values for $x$ are randomly chosen inside a plausible parameter value range $\left[x_{i, \text { low }} x_{i, \text { high }}-\Delta x_{i}\right]$, and $\Delta x_{i}$ is either 0 or a predetermined multiple of $1 /(p-1)$ with $p$ the number of considered parameter levels (rescaled at range $[0,1]$ ) for which $p / 2$ elementary effects are computed. In this study we took $p=8$, and fixed $\Delta x_{i}$ at $2 \times 1 /(8-1)$ on the $[0,1]$ rescaled range. The number 2 is an arbitrary choice in the Morris method (Morris, 1991); it determines what fraction of the plausible parameter range is covered by each elementary effect. The obtained elementary effects $u_{i}$ comprise a simple random sample, of which the mean $\mu_{i}$ and standard deviation $\sigma_{i}$ are used to assess how important a factor is. Hereto, a graph is made displaying the position of a factor $i$ in terms of $\mu *_{i}$ (the average of $\left.\left|u_{i}\right|\right)$ and $\sigma_{i}$. If the value of $\mu *_{i}$ is high, then there is a high linear effect of factor $i$; large values of $\sigma_{i}$ indicate either non-linear behavior of the model for factor $i$ or non-additive behavior (relative to other parameter values). In this study we took eight parameter levels, resulting in four elementary effects, for each one of eight model parameters. Thus, 64 simulations (32 pairs) for a period of $1000 \mathrm{yr}$ were done for a typical loess forest soil in Belgium (2.5 m depth with a vertical discretization of $5 \mathrm{~cm}$ at the Uccle Plateau location) and 64 more for a loess forest soil in China $(1.5 \mathrm{~m}$ depth with the same vertical discretization at pedon of LJB). This comprised about 85-CPU-day simulation time on one core (less than 6 days on four quad-core PCs), which was considered feasible. The model output parameters considered were OC (ton ha ${ }^{-1}$ ) in ectorganic layers and OC (mass ton ha ${ }^{-1}$ and content $\%$ ) in the mineral soil. Separate analyses were done for ectorganic layers and endorganic layers, because later calibration would focus on the vertical distribution of OC.

\subsection{Calibration and validation approach}

Calibration is the process of modifying the input parameters to a model until the output from the model matches an observed set of data. Various techniques also have been developed for model calibration, which differ in how parameter combinations are generated and how results are compared. In many cases, the modeler selects parameter combinations and evaluates results by expert judgment, in which case calibration is more or less a skill and may not detect the optimal parameter combinations. An alternative, often used technique is the minimization of an object function describing the deviations between measurements and simulations for various settings of parameters. The minimization process advises on optimal parameter combinations under the assumption that model outputs are differentiable with respect to the model parameters.

A well-known implementation is the PEST software (Doherty, 2004). Model runs are sequential, and the software decides if a new run with changed parameter settings is needed after results of a preceding run have been confronted to measurements by evaluating the object function. Another emerging method is the exploration of parameter space by a Markov chain Monte Carlo method. Model results are evaluated by calculating the posterior probability of the parameter set given the data, using the prior distribution of the parameters and a likelihood that expresses the correspondence between measurements and simulations. Of this Bayesian calibration method, various implementations exist, but even the most efficient ones (Vrugt et al., 2009) require numerous simulations. With time-consuming models such as SoilGen, convergence may take very long both in PEST and in Bayesian calibration. Finke (2012) used therefore an alternative approach in which various chosen sets of parameters were run with the model in parallel, confronting the model with measured data to quantify simulation accuracy and fitting a polynomial function predicting simulation accuracy as a function of parameter value. Analyzing the partial derivatives of this function, the position in parameter space with optimal simulation results was predicted. This approach may not find the true optimal parameter set and also depends on the choice of the evaluated parameter values. However, for reasons of runtime it was applied in Finke (2012).

The overall procedure of calibration is given in Fig. 2, following the principle of minimizing the difference between measured and simulated OC step by step. During the steps, parallel tests were firstly done for soil pedons by varying the most sensitive parameters identified in sensitivity analysis. Then the results were evaluated according to the quality indices described below. If there was still possibility to reduce the difference between measured and simulated OC by varying the same parameter, more parallel tests would be done in a sub-range of the parameter; otherwise, the next, less sensitive, parameter would be selected for tests. The process would be repeated, according to the order of parameter sensitivity, until no improvement was identified. In both studied regions, the difference of simulated and measured total carbon of the whole pedon was firstly minimized. In the second stage, the distribution of $\mathrm{OC}$ over ectorganic and endorganic layers was calibrated. 


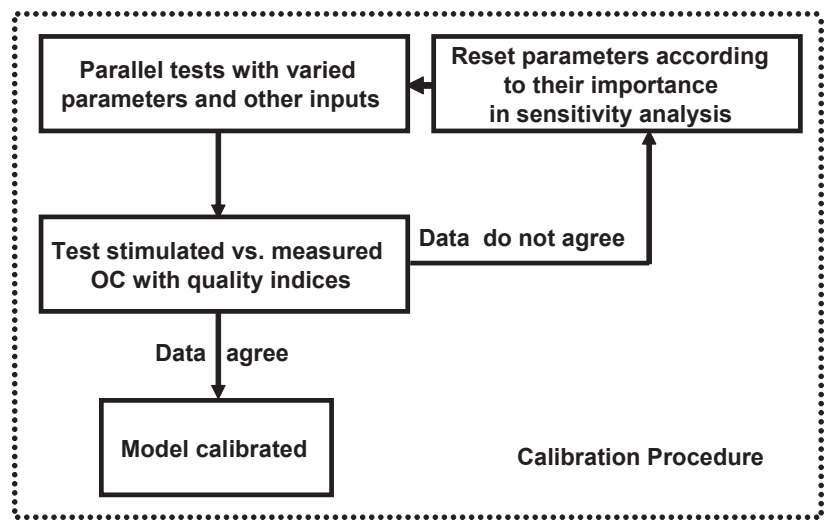

Fig. 2. Calibration procedure for OC cycle in SoilGen2 and the order of events.

The calibration aims at minimizing the number of runs by a quick convergence between simulated and measured OC. First, the quantitative relationships between changed $\mathrm{OC}$ and calibrated parameters revealed by sensitivity analysis were used to set limits to the variation range of the parameters. Second, a convergence criterion $(<5 \%)$ was applied to a particular quality index during the calibration. Calibration for each parameter was stopped when the best result was less than $5 \%$ better than the second best result (relative to the value of the quality index of the first simulation).

The number of soil pedons per region (3) was low because of the large input requirements of the model. We identified the stability of the calibration result by repeating the calibration three times per region. Each time, two of three soil pedons in each region were used to calibrate the model, while the third one was used for validation.

The indices used for assessing the quality of the C-module of SoilGen2 are the following:

1. root mean square deviation (RMSE) of total simulated and measured OC mass per mineral soil compartment:

RMSE1 $_{\text {endo,pedon }}=$

$$
\sqrt{\frac{\sum_{k=1}^{K}\left(\left(f_{\mathrm{OC}_{\mathrm{M}_{k}}} \times \rho_{\mathrm{M}_{k}} \times T_{k}\right)-\left(f_{\mathrm{OC}_{\mathrm{s}_{k}}} \times \rho_{\mathrm{S}_{k}} \times T_{k}\right)\right)^{2}}{K}}
$$

where $f_{\mathrm{OCM}}$ and $f_{\mathrm{OCS}}$ are measured and simulated OC mass, respectively, $\rho_{\mathrm{M}}$ and $\rho_{\mathrm{S}}$ measured and simulated bulk density $\left(\mathrm{kg} \mathrm{dm}^{-3}\right)$, and $T$ the thickness of the $k$ soil compartments (all equal to $50 \mathrm{~mm}$ ). RMSE $1_{\text {endo,pedon of }}$ the two pedons in each group of pedons in each region are averaged to obtain RMSE1 $1_{\text {endo }}$;
2. RMSE of total simulated and measured OC mass in the ectorganic layer:

$\mathrm{RMSE}_{\text {ecto }}=$

$$
\sqrt{\frac{1}{N} \times \sum_{n=1}^{N}\left(f_{\mathrm{OCM}_{n}} \times \rho_{\mathrm{M}_{n}} \times T_{n}-\mathrm{OC}_{\mathrm{S}_{n}}\right)^{2}}
$$

where $\mathrm{OC}_{\mathrm{S}}$ is the simulated OC mass in ectorganic layers and $n$ is the number of pedons (two per group of pedons in each region);

3. RMSE of total simulated and measured OC mass in the whole soil pedon:

$$
\mathrm{RMSE}_{\mathrm{OCMS}}=
$$

$$
\sqrt{\frac{1}{N} \times \sum_{n=1}^{N}\left(\left(\sum_{k=1}^{K}\left(f_{\mathrm{OCM}_{k, n}} \times \rho_{\mathrm{M}_{k, n}} \times T_{k, n}\right)+f_{\mathrm{OCM}_{n}} \times \rho_{\mathrm{M}_{n}} \times T_{n}\right)-\left(\sum_{k=1}^{K}\left(f_{\mathrm{OCS}_{k, n}} \times \rho_{\mathrm{S}_{k, n}} \times T_{k, n}\right)+\mathrm{OC}_{\mathrm{S}_{n}}\right)\right)^{2}}
$$

4. mean difference (MD) of total simulated and measured OC mass in mineral soil:

$$
\begin{aligned}
\mathrm{MD}_{\text {endo }} & = \\
& \frac{1}{N} \times \sum_{n=1}^{N}\left(\sum_{k=1}^{K}\left(f_{\mathrm{OCM}_{k, n}} \times \rho_{\mathrm{M}_{k, n}} \times T_{k, n}\right)\right. \\
& \left.-\sum_{k=1}^{K}\left(f_{\mathrm{OCS}_{k, n}} \times \rho_{\mathrm{S}_{k, n}} \times T_{k, n}\right)\right) ;
\end{aligned}
$$

5. MD of total simulated and measured OC mass in ectorganic layers:

$$
\mathrm{MD}_{\text {ecto }}=\frac{1}{N} \times \sum_{n=1}^{N}\left(f_{\mathrm{OCM}_{n}} \times \rho_{\mathrm{M}_{n}} \times T_{n}-\mathrm{OC}_{\mathrm{S}_{n}}\right) ;
$$

6. MD of total simulated and measured OC mass in the whole soil pedon:

$$
\mathrm{MD}_{\mathrm{OCMS}}=\mathrm{MD}_{\text {endo }}+\mathrm{MD}_{\text {ecto }}
$$

7. RMSE of simulated and measured OC \% in mineral soil:

RMSE2 2 endo,pedon $=$

$$
\sqrt{\frac{\sum_{k=1}^{K}\left(\left(f_{\mathrm{OCM}_{k}} \times 100\right)-\left(f_{\mathrm{OCS}_{k}} \times 100\right)\right)^{2}}{K}}
$$

which is averaged over two pedons to obtain RMSE2 ${ }_{\text {endo }}$; 
8. dissimilarity (DIS) (Gower, 1971) of simulated and measured OC \% in mineral soil:

$$
\begin{aligned}
& \mathrm{DIS}_{\text {pedon }}= \\
& \frac{1}{K \times\left(\mathrm{OC} \%_{\max }-\mathrm{OC} \%_{\min }\right)} \\
& \times \sum_{k=1}^{K} \mathrm{abs}\left(f_{\mathrm{OCM}_{k}} \times 100-f_{\mathrm{OCS}_{k}} \times 100\right)
\end{aligned}
$$

where $\mathrm{OC} \%_{\max }$ and $\mathrm{OC} \%_{\min }$ are the maximal and minimal value found in a particular pedon. DIS $\mathrm{OC} \%$ is calculated by averaging over two pedons and varies between 0 (perfect) and 1 (very poor). DIS gives the absolute difference as a fraction of the observed differences and thus is dimensionless. Therefore, it allows to compare results over different output parameters, which is not possible with other indices.

Of these statistics, the first six express how well the total OC mass in the soil is simulated, while the last two express how well the vertical distribution of OC content over the pedon is simulated. The MD statistics indicate systematic under- or overestimation of simulated values relative to measurements, while the RMSE statistics focus on the absolute values of these differences. Both are ideally close to 0 . The improvement of RMSE $E_{O C M S}$ (IM_RMSE $E_{O C M S}$ ) was used as convergence criterion in the first stage of calibration, while IM_RMSE $E_{\text {ecto }}$ and IM_RMSE $E_{\text {endo }}$ were used in the second stage.

\section{Results and discussion}

\subsection{Sensitivity analysis}

Table 2 gives the model parameters that were considered in the sensitivity analysis and the plausible range of these parameters. In Fig. 3, at a double-logarithmic scale, the $\mu *$ and $\sigma$ of the elementary effects of the eight factors are shown. The $\mu$ values for all rate factors were negative, which was expected because these describe decomposition and positive values for $\Delta x_{i}$, leading to higher values for $k$, and are expected to lead to lower amounts of remaining OC.

The OC mass in ectorganic layers and endorganic layers and the OC \% in endorganic layers respond most sensitively to the decomposition rate of humus $k_{\mathrm{HUM}}$ and less sensitive to the fraction of dead plant material entering the soil as leaf litter $\mathrm{fr}_{\text {ecto }}, k_{\mathrm{RPM}}$, and scalfac. The other factors show less sensitivity. Most responses are between the $|\mu|=$ SEM (stand error of the mean) and $|\mu|=2 *$ SEM lines indicating a fair confidence level. Most certain response of the sensitive factors is that of $\mathrm{fr}_{\text {ecto }}$, while the other factors are less certain. This may be caused by non-linear response or non-additive behavior (the model responds to interactions of factors).

The sensitivity order in the ectorganic layer is similar to that of the mineral soil, except for $k_{\mathrm{RPM}}$ and frecto. $k_{\mathrm{RPM}}$ is
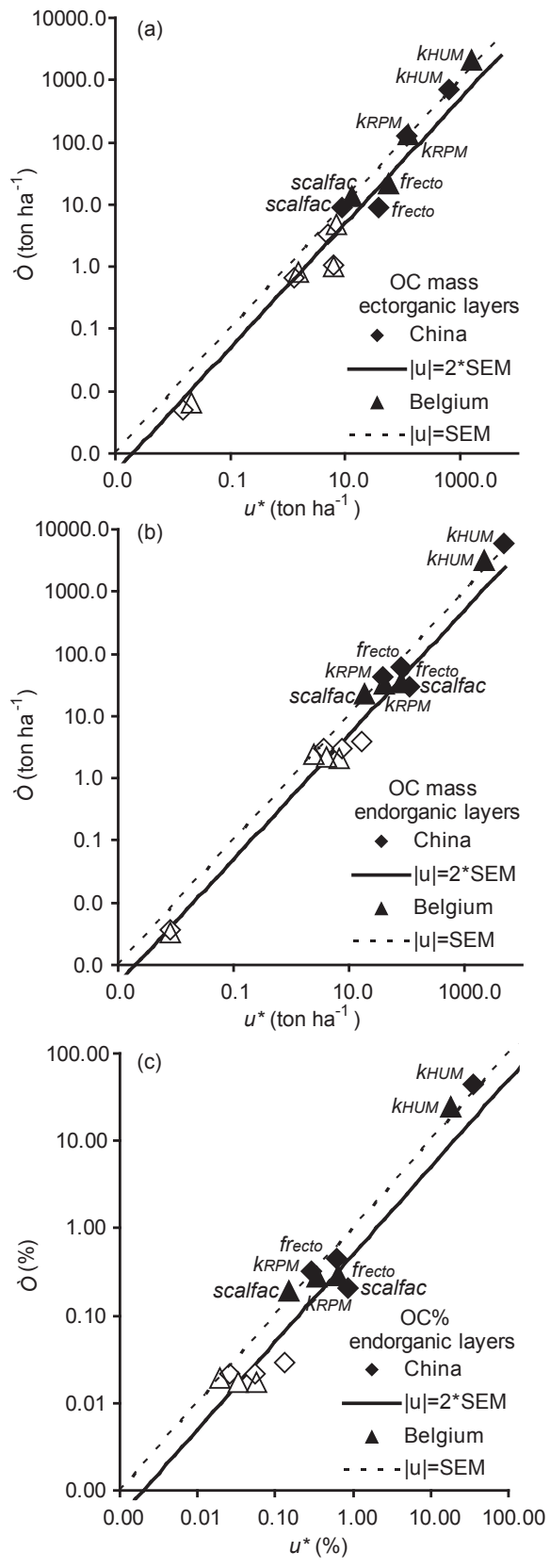

Fig. 3. Estimated means $(\mu *)$ and standard deviations $(\sigma)$ of the distribution of elementary effects of factors on OC. (a) OC mass in ectorganic layers; (b) OC mass in endorganic layers; (c) OC content in endorganic layers. Closed symbols with names indicate the 4 most important factors.

more important in the ectorganic layer; the rate modification due to moisture deficit is always equal to 1 in ectorganic layers while it can decrease in the mineral soil (Coleman and Jenkinson, 2005). This results in stronger modified $k_{\mathrm{RPM}}$ in the ectorganic layer.

Comparison (Table 2 and Fig. 3) of results for the Chinese and Belgian loess forest soils shows that the sensitivity orders 
Table 2. Model parameters in the organic C-module in SoilGen2 and results of sensitivity analysis.

\begin{tabular}{|c|c|c|c|c|c|c|c|c|c|c|c|c|c|c|c|}
\hline \multirow[t]{3}{*}{ Factor } & \multirow[t]{3}{*}{ Meaning } & \multirow{3}{*}{$\begin{array}{l}\text { Default } \\
\text { value }\end{array}$} & \multirow{3}{*}{$\begin{array}{r}\text { Plausible } \\
\text { range }\end{array}$} & \multicolumn{4}{|c|}{$\begin{array}{l}\text { OC ectorganic) } \\
\left(\text { ton } \mathrm{ha}^{-1}\right)\end{array}$} & \multicolumn{4}{|c|}{$\begin{array}{l}\text { OC endorganic } \\
\left(\text { ton ha }^{-1}\right)\end{array}$} & \multicolumn{4}{|c|}{$\begin{array}{l}\text { OC endorganic } \\
(\%)\end{array}$} \\
\hline & & & & \multicolumn{2}{|c|}{ Belgium } & \multicolumn{2}{|c|}{ China } & \multicolumn{2}{|c|}{ Belgium } & \multicolumn{2}{|c|}{ China } & \multicolumn{2}{|c|}{ Belgium } & \multicolumn{2}{|c|}{ China } \\
\hline & & & & $\mu^{*}$ & 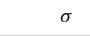 & $\mu^{*}$ & $\sigma$ & & $\sigma$ & $\mu^{*}$ & $\sigma$ & $\mu^{*}$ & $\sigma$ & $\mu^{*}$ & $\sigma$ \\
\hline$k_{\mathrm{HUM}}$ & $\begin{array}{l}\text { Decomposition rate }\left(\mathrm{yr}^{-1}\right) \text { of } \\
\text { humus }\end{array}$ & $0.02^{\mathrm{a}}$ & $0.005-0.035$ & 1569.08 & 2085.04 & 630.23 & 708.39 & 2218.87 & 3131.79 & 4796.81 & 6064.40 & 17.85 & 24.57 & 35.51 & 43.51 \\
\hline$k_{\mathrm{RPM}}$ & $\begin{array}{l}\text { Decomposition rate }\left(\mathrm{yr}^{-1}\right) \text { of } \\
\text { resistant plant material }\end{array}$ & $0.30^{\mathrm{a}}$ & $0.075-0.525$ & 120.60 & 131.04 & 119.36 & 129.70 & 40.41 & 33.22 & 80.47 & 61.18 & 0.34 & 0.28 & 0.61 & 0.46 \\
\hline frecto $_{\text {ect }}$ & $\begin{array}{l}\text { Fraction of incoming plant ma- } \\
\text { terial as leaf litter }\end{array}$ & $0.58^{\mathrm{b}}$ & $0.36-0.98$ & 56.21 & 21.55 & 38.50 & 9.17 & 77.92 & 35.29 & 110.43 & 29.42 & 0.65 & 0.29 & 0.84 & 0.21 \\
\hline scalfac & $\begin{array}{l}\text { Scaling factor for } \\
\mathrm{CO}_{2} /(\mathrm{BIO}+\mathrm{HUM}) \text { ratio }\end{array}$ & $1.67^{\mathrm{a}}$ & $0.4-3.0$ & 12.81 & 13.71 & 8.75 & 8.77 & 18.08 & 23.02 & 37.78 & 43.26 & 0.15 & 0.19 & 0.29 & 0.32 \\
\hline DPM / RPM & $\begin{array}{l}\text { Ratio decomposable/resistant } \\
\text { plant material in incoming } \\
\text { plant material }\end{array}$ & $0.25^{\mathrm{a}}$ & $0.1-0.5$ & 6.27 & 1.02 & 6.21 & 1.04 & 4.09 & 2.16 & 7.36 & 3.01 & 0.03 & 0.02 & 0.06 & 0.02 \\
\hline BIO / HUM & $\begin{array}{l}\text { Distribution ratio of } \\
\text { BIO+HUM }\end{array}$ & $0.85^{\mathrm{a}}$ & $0.68-1.02$ & 6.93 & 4.84 & 5.04 & 3.30 & 6.77 & 2.10 & 16.86 & 3.88 & 0.06 & 0.02 & 0.13 & 0.03 \\
\hline$k_{\mathrm{BIO}}$ & $\begin{array}{l}\text { Decomposition rate }\left(\mathrm{yr}^{-1}\right) \text { of } \\
\text { biomass }\end{array}$ & $0.66^{\mathrm{a}}$ & $0.165-1.155$ & 1.50 & 0.81 & 1.32 & 0.67 & 2.39 & 2.49 & 3.56 & 3.01 & 0.02 & 0.02 & 0.03 & 0.02 \\
\hline$k_{\mathrm{DPM}}$ & $\begin{array}{l}\text { Decomposition rate }\left(\mathrm{yr}^{-1}\right) \text { of } \\
\text { decomposable plant material }\end{array}$ & $10.00^{\mathrm{a}}$ & $2.5-17.5$ & 0.02 & 0.01 & 0.01 & 0.01 & 0.01 & 0.00 & 0.01 & 0.00 & 0.00 & 0.00 & 0.00 & 0.00 \\
\hline
\end{tabular}

a Source: RothC26.3. ${ }^{\text {b }}$ Source: SoilGen2.17, deciduous woodland.

of the factors follow the same pattern, irrespective of the differences in soil (the Belgian loess soil is strongly leached whereas the Chinese is not) and climate (a large precipitation surplus in Belgium and a large precipitation deficit in China). The values for $\mu *$ and $\sigma$ differ (Fig. 3), which is higher in endorganic layers in Chinese soil pedons but lower in ectorganic layers. Nevertheless, the sensitivity order is the same, which means that the same model parameters could be selected for calibration in both soils: $k_{\mathrm{HUM}}, \mathrm{fr}_{\mathrm{ecto}}, k_{\mathrm{RPM}}$ and scalfac.

\subsection{Calibration and validation}

Based on 67 and 57 test simulations, three sets of calibrated parameters were obtained for Belgium and China, respectively. Table 3 gives the model parameters in calibrations tests. Results comparing simulated and measured OC by eight quality indices are given in Figs. 4 and 5 and Table 3 , with lower absolute values of them indicating better simulated results.

In the stage of calibration (steps 2 and 3 in Table 3), tests (1bs and 1cs) with default values of parameters in SoilGen2 (step 1 in Table 3) showed that simulated total OC mass was lower than measured ones in both regions with larger deviations in Belgium than in China (Fig. $4 d-f$ and $j-1$ ). The differences in total OC mass were minimized by decreasing the most sensitive parameter $k_{\mathrm{HUM}}$ and the second sensitive parameter $k_{\mathrm{RPM}}$ during the first calibration stage (Table 3). The IM_RMSE $\mathrm{OCMS}$ became much lower than $5 \%$, when $k_{\mathrm{HUM}}$ values were set as $0.0061-0.0065$ and 0.014 0.019 , and $k_{\mathrm{RPM}}$ values were $0.27-0.29$ and $0.25-0.29$ in Belgium and China, respectively. The RMSE $\mathrm{OCMS}$ resulting from these simulations served as target quality for the second stage of calibration.

The following calibrations for both regions were to adjust the distribution of $\mathrm{OC}$ in ectorganic (overestimation in stage 1) and endorganic (underestimation) layers. Based on tests in steps 4 in both regions with variation of $\mathrm{fr}_{\text {ecto, }}$, it was revealed that the decrease of $\mathrm{fr}_{\text {ecto }}$ could also increase the amount of OC mass in both layers (Table 3). In order to reduce this effect and the values of $\mathrm{RMSE}_{\text {ecto }}$ and RMSE $\mathrm{E}_{\text {endo }}$ simultaneously, $k_{\mathrm{HUM}}$ and $k_{\mathrm{RPM}}$ were increased slightly (steps 5 and 6 in Table 3). The best results were finally obtained in Test $21 \mathrm{~b} \_1$, Test $22 \mathrm{~b} \_2$ and Test22b_3 in Belgium and Test18c_1, Test17c $\_2$ and Test19c 3 in China with the following combination of parameters (Belgium, $k_{\mathrm{HUM}}=0.0065-0.0074, k_{\mathrm{RPM}}=0.27-$ 0.27 and fr $_{\text {ecto }}=0.30-0.38$; China, $k_{\mathrm{HUM}}=0.016-0.019$, $k_{\mathrm{RPM}}=0.30-0.30$ and $\mathrm{fr}_{\text {ecto }}=0.37-0.43$ ), with the lowest values of IM_RMSE $E_{\text {ecto }}$ and IM_RMSE $E_{\text {endo }}$ at the same time while the RMSEOCMS remained close to the value reached in the first stage of the calibration.

Above tests were further confirmed as the best calibration results by comparing eight quality indices synthetically (Table 3 and Fig. 4), because the indices of them all belong to the lower ones in all tests of two regions. Figure 5 further shows that the simulated vertical distributions of OC content are also similar to measured ones visually.

The comparisons between measured and simulated OC of the validation pedons are given in Fig. 6. Two groups of OC mass are evenly distributed along $1: 1$ line (Fig. 6a), and RMSE $E_{O C M S}$ values of pedons are all less than $12 \%$ of the total OC mass. Furthermore, the consistency is also evident in vertical distributions of OC content (Fig. 6b-g).

This two-stage calibration approach was repeated three times, always calibrating with two pedons in a region while checking the quality with the third pedon. Results indicate that the calibration results are fairly stable and independent on the subset of two pedons chosen for the calibration. This suggests that the calibrated parameters are applicable to other soil pedons in similar climate conditions. 
Table 3. Model parameters in the organic C-module in SoilGen2 and quality indices of one group of pedons during the calibration in Belgium and China. Bold numbers indicate the best calibration results for each group of pedons.

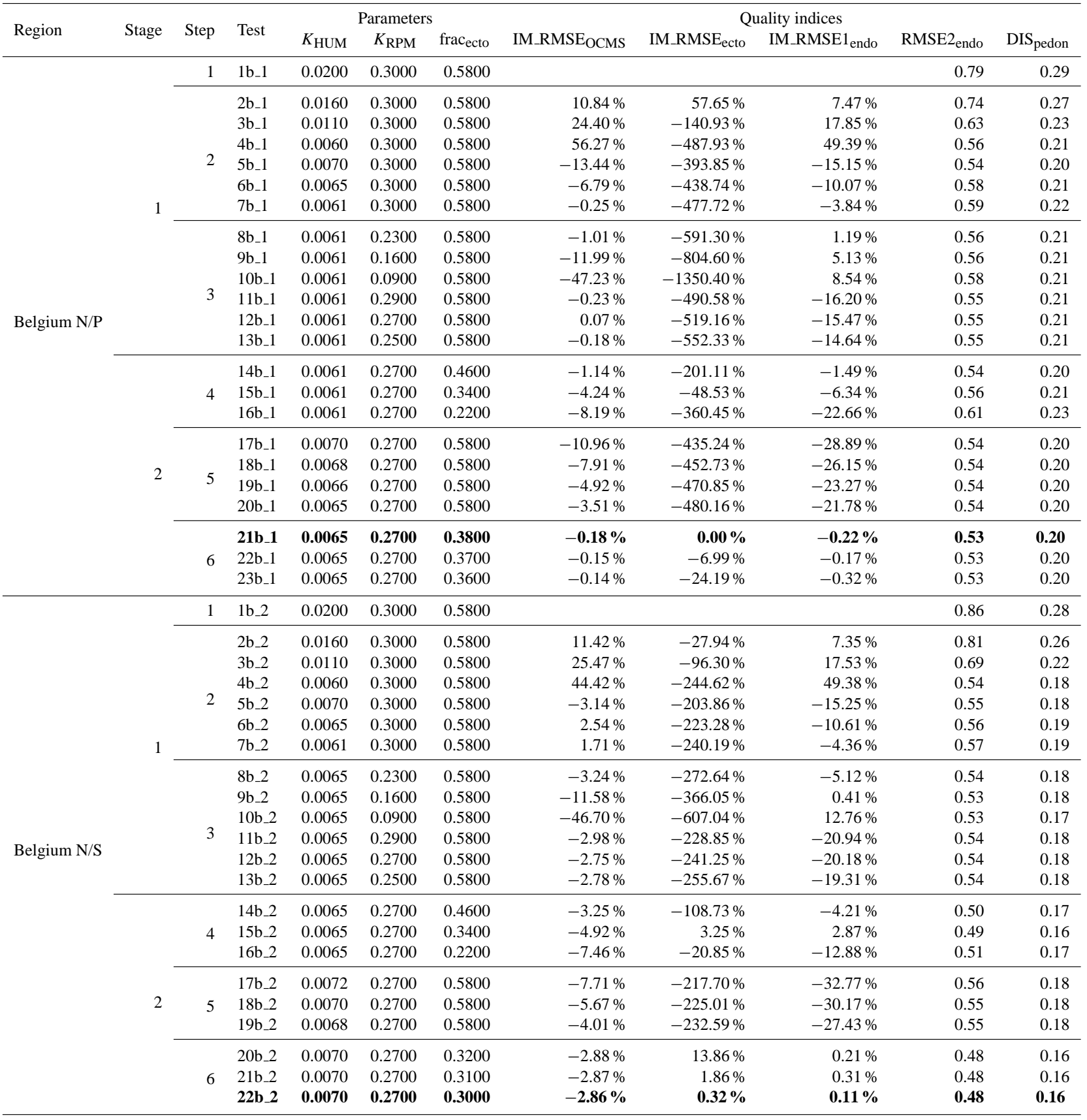

\subsection{Comparison}

\subsubsection{Comparison with former studies}

Our results of sensitivity analysis are in accordance with former studies on RothC model in surface forest soils (Paul and Polglase, 2004; Paul et al., 2003), which indicated that change in soil carbon is particularly sensitive to the decomposition rates of HUM, RPM and BIO pools. Comparing that only the relative importance of the parameters was shown in former analysis (Paul and Polglase, 2004; Paul et al., 2003), a quantitative evaluation of their importance is given in our study and the especially significant sensitivity of $k_{\mathrm{HUM}}$ is revealed.

The calibrated values of parameters $\left(k_{\mathrm{HUM}}\right.$ and $\left.k_{\mathrm{RPM}}\right)$ in our study all fall into the logical range of former calibrations for RothC model (Shirato et al., 2004; Skjemstad et al., 2004; Todorovic et al., 2010), covering various climate conditions 
Table 3. Continued.

\begin{tabular}{|c|c|c|c|c|c|c|c|c|c|c|c|}
\hline \multirow{2}{*}{ Region } & \multirow{2}{*}{ Stage } & \multirow{2}{*}{ Step } & \multirow{2}{*}{ Test } & \multicolumn{3}{|c|}{ Parameters } & \multicolumn{5}{|c|}{ Quality indices } \\
\hline & & & & $K_{\mathrm{HUM}}$ & $K_{\mathrm{RPM}}$ & fracecto $_{\text {ect }}$ & IM_RMSE & IM_RMSE $E_{\text {ecto }}$ & IM_RMSE $1_{\text {endo }}$ & RMSE2 $_{\text {endo }}$ & DIS $_{\text {pedon }}$ \\
\hline \multirow{22}{*}{ Belgium P/S } & \multirow{13}{*}{1} & 1 & $1 b \_3$ & 0.0200 & 0.3000 & 0.5800 & & & & 0.65 & 0.33 \\
\hline & & \multirow{6}{*}{2} & $2 b_{3} 3$ & 0.0160 & 0.3000 & 0.5800 & $12.83 \%$ & $-19.21 \%$ & $8.23 \%$ & 0.60 & 0.31 \\
\hline & & & 3b_3 & 0.0110 & 0.3000 & 0.5800 & $28.87 \%$ & $-75.60 \%$ & $19.73 \%$ & 0.50 & 0.25 \\
\hline & & & $4 b \_3$ & 0.0060 & 0.3000 & 0.5800 & $38.04 \%$ & $-208.78 \%$ & $56.58 \%$ & 0.48 & 0.23 \\
\hline & & & $5 b \_3$ & 0.0070 & 0.3000 & 0.5800 & $9.76 \%$ & $-171.64 \%$ & $-17.93 \%$ & 0.44 & 0.22 \\
\hline & & & $6 \mathrm{~b} \_3$ & 0.0065 & 0.3000 & 0.5800 & $1.83 \%$ & $-189.30 \%$ & $-15.61 \%$ & 0.51 & 0.24 \\
\hline & & & $7 b \_3$ & 0.0061 & 0.3000 & 0.5800 & $-3.59 \%$ & $-204.73 \%$ & $-8.58 \%$ & 0.53 & 0.24 \\
\hline & & \multirow{6}{*}{3} & $8 b_{3} 3$ & 0.0065 & 0.2300 & 0.5800 & $-8.67 \%$ & $-234.43 \%$ & $-6.18 \%$ & 0.45 & 0.22 \\
\hline & & & $9 b_{-} 3$ & 0.0065 & 0.1600 & 0.5800 & $-24.37 \%$ & $-320.37 \%$ & $0.30 \%$ & 0.46 & 0.22 \\
\hline & & & $10 b_{-} 3$ & 0.0065 & 0.0900 & 0.5800 & $-67.16 \%$ & $-543.48 \%$ & $13.09 \%$ & 0.49 & 0.23 \\
\hline & & & 11b_3 & 0.0065 & 0.2900 & 0.5800 & $-2.67 \%$ & $-194.38 \%$ & $-22.63 \%$ & 0.45 & 0.22 \\
\hline & & & $12 b_{3} 3$ & 0.0065 & 0.2700 & 0.5800 & $-4.15 \%$ & $-205.70 \%$ & $-21.76 \%$ & 0.45 & 0.22 \\
\hline & & & $13 \mathrm{~b} \_3$ & 0.0065 & 0.2500 & 0.5800 & $-6.12 \%$ & $-218.88 \%$ & $-20.75 \%$ & 0.45 & 0.22 \\
\hline & \multirow{9}{*}{2} & \multirow{3}{*}{4} & $14 b \_3$ & 0.0065 & 0.2900 & 0.4600 & $-6.50 \%$ & $-78.31 \%$ & $-3.46 \%$ & 0.43 & 0.21 \\
\hline & & & $15 b_{-} 3$ & 0.0065 & 0.2900 & 0.3400 & $-11.11 \%$ & $3.93 \%$ & $-12.10 \%$ & 0.43 & 0.21 \\
\hline & & & $16 \mathrm{~b} \_3$ & 0.0065 & 0.2900 & 0.2200 & $-16.07 \%$ & $-41.64 \%$ & $-31.49 \%$ & 0.48 & 0.23 \\
\hline & & \multirow{3}{*}{5} & 17b_3 & 0.0074 & 0.2700 & 0.5800 & $-4.54 \%$ & $-178.78 \%$ & $-35.91 \%$ & 0.43 & 0.22 \\
\hline & & & $18 b \_3$ & 0.0072 & 0.2700 & 0.5800 & $-2.16 \%$ & $-185.19 \%$ & $-33.07 \%$ & 0.43 & 0.22 \\
\hline & & & $19 b \_3$ & 0.0070 & 0.2700 & 0.5800 & $-0.67 \%$ & $-191.85 \%$ & $-30.06 \%$ & 0.44 & 0.22 \\
\hline & & \multirow{3}{*}{6} & 20b_3 & 0.0074 & 0.2700 & 0.3500 & $-0.53 \%$ & $0.48 \%$ & $-1.45 \%$ & 0.38 & 0.20 \\
\hline & & & $21 b_{-} 3$ & 0.0074 & 0.2700 & 0.3400 & $-0.50 \%$ & $1.97 \%$ & $-0.17 \%$ & 0.38 & 0.20 \\
\hline & & & $22 b \_3$ & 0.0074 & 0.2700 & 0.3300 & $-0.49 \%$ & $0.88 \%$ & $0.56 \%$ & 0.38 & 0.20 \\
\hline \multirow{19}{*}{ China LJB/ZW2 } & \multirow{13}{*}{1} & 1 & $1 \mathrm{c}_{-} 1$ & 0.020 & 0.300 & 0.580 & & & & 0.68 & 0.18 \\
\hline & & \multirow{6}{*}{2} & $2 c_{-} 1$ & 0.016 & 0.300 & 0.580 & $42.57 \%$ & $-23.22 \%$ & $32.20 \%$ & 0.62 & 0.16 \\
\hline & & & $3 c_{-} 1$ & 0.011 & 0.300 & 0.580 & $-37.79 \%$ & $-63.49 \%$ & $13.72 \%$ & 0.52 & 0.15 \\
\hline & & & $4 c_{-} 1$ & 0.006 & 0.300 & 0.580 & $-301.80 \%$ & $-125.70 \%$ & $-185.47 \%$ & 0.56 & 0.17 \\
\hline & & & $5 c_{1}$ & 0.015 & 0.300 & 0.580 & $8.72 \%$ & $-30.10 \%$ & $-4.52 \%$ & 0.60 & 0.16 \\
\hline & & & $6 c_{-} 1$ & 0.014 & 0.300 & 0.580 & $3.08 \%$ & $-37.50 \%$ & $4.18 \%$ & 0.58 & 0.16 \\
\hline & & & $7 \mathrm{c} \_1$ & 0.013 & 0.300 & 0.580 & $-6.69 \%$ & $-45.48 \%$ & $6.13 \%$ & 0.56 & 0.15 \\
\hline & & \multirow{6}{*}{3} & $8 \mathrm{c} \_1$ & 0.014 & 0.230 & 0.580 & $-11.02 \%$ & $-93.16 \%$ & $-0.33 \%$ & 0.57 & 0.16 \\
\hline & & & $9 c_{-} 1$ & 0.014 & 0.160 & 0.580 & $-58.42 \%$ & $-198.38 \%$ & $0.13 \%$ & 0.54 & 0.15 \\
\hline & & & $10 \mathrm{c}_{-} 1$ & 0.014 & 0.090 & 0.580 & $-205.00 \%$ & $-468.32 \%$ & $-43.35 \%$ & 0.51 & 0.16 \\
\hline & & & $11 c_{-} 1$ & 0.014 & 0.290 & 0.580 & $-0.25 \%$ & $-43.79 \%$ & $-5.44 \%$ & 0.58 & 0.16 \\
\hline & & & $12 \mathrm{c}_{-} 1$ & 0.014 & 0.270 & 0.580 & $-1.81 \%$ & $-57.74 \%$ & $-3.76 \%$ & 0.58 & 0.16 \\
\hline & & & $13 \mathrm{c}_{-} 1$ & 0.014 & 0.250 & 0.580 & $-5.25 \%$ & $-74.04 \%$ & $-2.07 \%$ & 0.57 & 0.16 \\
\hline & \multirow{6}{*}{2} & \multirow{3}{*}{4} & $14 c_{-} 1$ & 0.014 & 0.290 & 0.460 & $-10.88 \%$ & $39.77 \%$ & $-0.75 \%$ & 0.56 & 0.16 \\
\hline & & & $15 \mathrm{c}_{-} 1$ & 0.014 & 0.290 & 0.340 & $-28.32 \%$ & $22.36 \%$ & $-22.90 \%$ & 0.55 & 0.17 \\
\hline & & & $16 c_{-} 1$ & 0.014 & 0.290 & 0.220 & $-48.04 \%$ & $-80.84 \%$ & $-54.20 \%$ & 0.56 & 0.18 \\
\hline & & \multirow{3}{*}{5} & $17 \mathrm{c}_{-} 1$ & 0.016 & 0.300 & 0.430 & $-1.11 \%$ & $8.76 \%$ & $1.22 \%$ & 0.58 & 0.16 \\
\hline & & & $18 c \_1$ & 0.016 & 0.300 & 0.400 & $-0.99 \%$ & $\mathbf{0 . 5 3} \%$ & $0.05 \%$ & 0.58 & 0.16 \\
\hline & & & $19 c_{-} 1$ & 0.016 & 0.300 & 0.370 & $-1.56 \%$ & $-9.06 \%$ & $-1.04 \%$ & 0.57 & 0.17 \\
\hline
\end{tabular}

and soil types, They are lower than default values in RothC model, which was originally developed and parameterized in surface agricultural soils $(0-30 \mathrm{~cm})$ (Jenkinson, 1990). The difference may be attributed to following aspects: firstly, decomposition in agricultural soils is faster than that in forest soils because of its lower lignin content in litter (Lambers et al., 1998) and more favorable micro-climate conditions for decomposition induced by human disturbance (Schlesinger and Andrews, 2000); secondly, carbon at deeper depth (1.5$2.5 \mathrm{~m}$ in our study) is older than that near the surface, indicating that it has a greater resistance to decomposition or that the environment at depth is less favorable for decomposition processes (Swift, 2001).
The calibrated $\mathrm{fr}_{\text {ecto }}$ is lower than the default value (0.58) in SoilGen2 based on measured data (Kononova, 1975). In realistic soil carbon cycle process, part of litter carbon pool in ectorganic layer leaches to endorganic layers in the form of dissolved organic carbon (DOC). However, this process is not simulated in SoilGen2, while only little carbon is being exchanged between two layers by bioturbation in the model. Therefore, $\mathrm{fr}_{\text {ecto }}$, as the ratio of carbon pool in ectorganic layer to the total pool, was expected to be lower than the literature value as this decrease mimics the effect of DOCleaching. 
Table 3. Continued.

\begin{tabular}{|c|c|c|c|c|c|c|c|c|c|c|c|}
\hline \multirow{2}{*}{ Region } & \multirow{2}{*}{ Stage } & \multirow{2}{*}{ Step } & \multirow{2}{*}{ Test } & \multicolumn{3}{|c|}{ Parameters } & \multicolumn{5}{|c|}{ Quality indices } \\
\hline & & & & $K_{\mathrm{HUM}}$ & $K_{\mathrm{RPM}}$ & frac $_{\text {ecto }}$ & IM_RMSE $\mathrm{OCMS}$ & IM_RMSE $E_{\text {ecto }}$ & IM_RMSE $1_{\text {endo }}$ & RMSE2 $2_{\text {endo }}$ & DIS $_{\text {pedon }}$ \\
\hline \multirow{19}{*}{ China LJB/ZW3 } & \multirow{13}{*}{1} & 1 & $1 c \_2$ & 0.020 & 0.300 & 0.580 & & & & 0.70 & 0.13 \\
\hline & & \multirow{6}{*}{2} & $2 \mathrm{c} \_2$ & 0.016 & 0.300 & 0.580 & $27.24 \%$ & $-20.41 \%$ & $75.65 \%$ & 0.65 & 0.13 \\
\hline & & & $3 c \_2$ & 0.011 & 0.300 & 0.580 & $-297.86 \%$ & $-55.94 \%$ & $-130.46 \%$ & 0.58 & 0.13 \\
\hline & & & $4 c \_2$ & 0.006 & 0.300 & 0.580 & $-1016.44 \%$ & $-111.00 \%$ & $-548.35 \%$ & 0.70 & 0.18 \\
\hline & & & $5 c \_2$ & 0.019 & 0.300 & 0.580 & $-2.24 \%$ & $-4.58 \%$ & $-59.46 \%$ & 0.69 & 0.13 \\
\hline & & & $6 c \_2$ & 0.018 & 0.300 & 0.580 & $19.00 \%$ & $-9.51 \%$ & $-41.46 \%$ & 0.68 & 0.13 \\
\hline & & & $7 \mathrm{c} \_2$ & 0.017 & 0.300 & 0.580 & $4.11 \%$ & $-14.76 \%$ & $-21.42 \%$ & 0.66 & 0.13 \\
\hline & & \multirow{6}{*}{3} & $8 \mathrm{c} \_2$ & 0.019 & 0.230 & 0.580 & $-8.30 \%$ & $-53.30 \%$ & $-31.49 \%$ & 0.68 & 0.13 \\
\hline & & & $9 \mathrm{c} \_2$ & 0.019 & 0.160 & 0.580 & $-145.05 \%$ & $-146.18 \%$ & $10.41 \%$ & 0.65 & 0.14 \\
\hline & & & $10 \mathrm{c} \_2$ & 0.019 & 0.090 & 0.580 & $-542.17 \%$ & $-385.55 \%$ & $-118.09 \%$ & 0.63 & 0.15 \\
\hline & & & $11 c_{-} 2$ & 0.019 & 0.290 & 0.580 & $-18.45 \%$ & $-10.05 \%$ & $-66.68 \%$ & 0.69 & 0.13 \\
\hline & & & $12 c_{-} 2$ & 0.019 & 0.270 & 0.580 & $-6.20 \%$ & $-22.23 \%$ & $-59.62 \%$ & 0.69 & 0.13 \\
\hline & & & $13 c_{-} 2$ & 0.019 & 0.250 & 0.580 & $-0.38 \%$ & $-36.47 \%$ & $-51.44 \%$ & 0.68 & 0.13 \\
\hline & \multirow{6}{*}{2} & \multirow{3}{*}{4} & $14 c_{-} 2$ & 0.019 & 0.250 & 0.460 & $-26.63 \%$ & $36.16 \%$ & $-3.40 \%$ & 0.67 & 0.14 \\
\hline & & & $15 c_{-} 2$ & 0.019 & 0.250 & 0.340 & $-77.04 \%$ & $30.01 \%$ & $-70.33 \%$ & 0.67 & 0.15 \\
\hline & & & $16 c_{-} 2$ & 0.019 & 0.250 & 0.220 & $-129.95 \%$ & $-65.30 \%$ & $-140.89 \%$ & 0.68 & 0.16 \\
\hline & & \multirow{3}{*}{5} & $17 c_{-} 2$ & 0.019 & 0.300 & 0.430 & $1.97 \%$ & $2.24 \%$ & $-0.37 \%$ & 0.67 & 0.14 \\
\hline & & & $18 \mathrm{c}_{-} 2$ & 0.019 & 0.300 & 0.400 & $-7.13 \%$ & $-0.11 \%$ & $-11.41 \%$ & 0.67 & 0.14 \\
\hline & & & $19 \mathrm{c} \_2$ & 0.019 & 0.300 & 0.370 & $-15.68 \%$ & $-6.71 \%$ & $-26.73 \%$ & 0.67 & 0.14 \\
\hline \multirow{19}{*}{ China ZW2/ZW3 } & \multirow{13}{*}{1} & 1 & $1 \mathrm{c} \_3$ & 0.020 & 0.300 & 0.580 & & & & 0.64 & 0.22 \\
\hline & & \multirow{6}{*}{2} & $2 c \_3$ & 0.016 & 0.300 & 0.580 & $31.59 \%$ & $-18.94 \%$ & $29.72 \%$ & 0.60 & 0.21 \\
\hline & & & $3 c \_3$ & 0.011 & 0.300 & 0.580 & $-49.96 \%$ & $-51.98 \%$ & $11.77 \%$ & 0.54 & 0.19 \\
\hline & & & $4 c_{-} 3$ & 0.006 & 0.300 & 0.580 & $-326.56 \%$ & $-103.61 \%$ & $-189.92 \%$ & 0.56 & 0.23 \\
\hline & & & $5 c \_3$ & 0.015 & 0.300 & 0.580 & $3.58 \%$ & $-24.57 \%$ & $-3.37 \%$ & 0.59 & 0.20 \\
\hline & & & $6 c \_3$ & 0.014 & 0.300 & 0.580 & $-1.86 \%$ & $-30.63 \%$ & $4.42 \%$ & 0.58 & 0.20 \\
\hline & & & $7 c_{-} 3$ & 0.013 & 0.300 & 0.580 & $-11.07 \%$ & $-37.18 \%$ & $5.31 \%$ & 0.57 & 0.19 \\
\hline & & \multirow{6}{*}{3} & $8 \mathrm{c} \_3$ & 0.015 & 0.230 & 0.580 & $-6.07 \%$ & $-67.42 \%$ & $-5.39 \%$ & 0.59 & 0.20 \\
\hline & & & $9 \mathrm{c} \_3$ & 0.015 & 0.160 & 0.580 & $-47.82 \%$ & $-147.95 \%$ & $0.97 \%$ & 0.58 & 0.20 \\
\hline & & & $10 c_{-} 3$ & 0.015 & 0.090 & 0.580 & $-196.72 \%$ & $-354.04 \%$ & $-33.86 \%$ & 0.58 & 0.22 \\
\hline & & & $11 c_{-} 3$ & 0.015 & 0.290 & 0.580 & $0.17 \%$ & $-29.40 \%$ & $-13.09 \%$ & 0.59 & 0.20 \\
\hline & & & $12 c_{-} 3$ & 0.015 & 0.270 & 0.580 & $-0.45 \%$ & $-40.19 \%$ & $-11.00 \%$ & 0.59 & 0.20 \\
\hline & & & $13 c_{-} 3$ & 0.015 & 0.250 & 0.580 & $-2.34 \%$ & $-52.72 \%$ & $-8.74 \%$ & 0.59 & 0.20 \\
\hline & & \multirow{3}{*}{4} & $14 c_{-} 3$ & 0.015 & 0.290 & 0.460 & $-4.49 \%$ & $35.77 \%$ & $-0.13 \%$ & 0.60 & 0.21 \\
\hline & & & $15 c_{-} 3$ & 0.015 & 0.290 & 0.340 & $-16.28 \%$ & $56.07 \%$ & $-13.41 \%$ & 0.61 & 0.22 \\
\hline & 2 & & $16 c_{-} 3$ & 0.015 & 0.290 & 0.220 & $-32.22 \%$ & $-59.41 \%$ & $-41.21 \%$ & 0.64 & 0.24 \\
\hline & 2 & \multirow{3}{*}{5} & $17 c_{-} 3$ & 0.017 & 0.300 & 0.430 & $-0.84 \%$ & $-28.45 \%$ & $-3.36 \%$ & 0.61 & 0.21 \\
\hline & & & $18 c_{-} 3$ & 0.017 & 0.300 & 0.400 & $-0.23 \%$ & $-13.68 \%$ & $-0.98 \%$ & 0.62 & 0.22 \\
\hline & & & 19c_3 & 0.017 & 0.300 & 0.370 & $-0.15 \%$ & $-1.07 \%$ & $-0.14 \%$ & 0.62 & 0.22 \\
\hline
\end{tabular}

\subsubsection{Comparison between two regions}

Although the orders of sensitivity for parameters are the same in two regions, the responses are less significant in Belgian soil pedons (Table 2). It led to corresponding larger ranges of parameters $\left(k_{\mathrm{HUM}}, \mathrm{fr}_{\text {ecto }}\right.$ and $\left.k_{\mathrm{RPM}}\right)$ that varied during calibration in Belgium (Table 3), which shows slower decomposition rate of $\mathrm{OC}$ in Belgian soils. The differences may be driven by the following reasons.

Firstly, litter chemical composition is one of the most important factors that affect decomposition of litter. Especially in late stage of decomposition for the formation of humus, lignin decomposition exerts the dominant control in soils (Berg and McClaugherty, 2008; Quideau et al., 2001), which is relatively resistant to decomposition (Lambers et al., 1998). Since the study area in Belgium is under beech forest while it is under poplar in China, higher lignin and holocellulose contents in the former ecosystem compared to the later (Coldwell and Delong, 1950) induce slower decomposition rate of OC in Belgium than in China, which is reflected by lower decomposition coefficients $\left(k_{\mathrm{HUM}}, \mathrm{fr}_{\text {ecto }}\right.$ and $\left.k_{\mathrm{RPM}}\right)$ of resistant carbon pools.

Secondly, the distribution of temperature, precipitation and evaporation over the year also affects the decomposition rate and the loss of carbon from soil (Raich and Tufekcioglu, 2000; Schimel et al., 1994). High temperatures accompanied by significant rain occur in the summer monsoon climate of China, which could lead to quicker litter decomposition (Raich and Tufekcioglu, 2000; Zhang et al., 2008) without any limit of energy or moisture in this season. The different influences of climate conditions on decomposition process in two regions may be reflected indirectly by setting different 

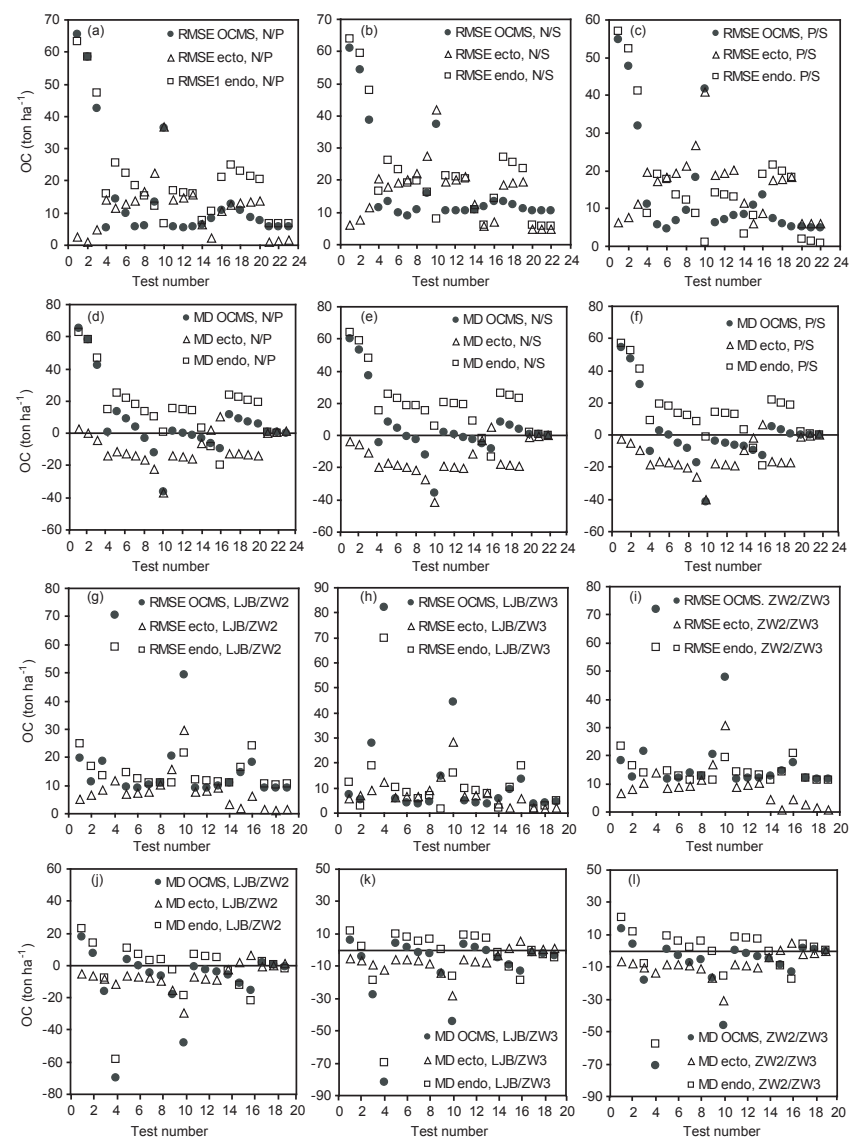

Fig. 4. Quality indices for calibration results. (a) RMSE of average OC mass in N/P pedons in Belgium; (b) RMSE of average OC mass in N/S pedons in Belgium; (c) RMSE of average OC mass in $\mathrm{P} / \mathrm{S}$ pedons in Belgium; (d) MD of average OC mass in N/P pedons in Belgium; (e) MD of average OC mass in N/S pedons in Belgium; (f) MD of average OC mass in P/S pedons in Belgium; (g) RMSE of average OC mass in LJB/ZW2 pedons in China; (h) RMSE of average OC mass in LJB/ZW3 pedons in China; (i) RMSE of average OC mass in ZW2/ZW3 pedons in China; (j) MD of average OC mass in LJB/ZW2 pedons in China; (k) MD of average OC mass in LJB/ZW3 pedons in China; (l) MD of average OC mass in ZW2/ZW3 pedons in China.

values of these parameters, because just decomposition coefficients $\left(k_{\mathrm{HUM}}, \mathrm{fr}_{\text {ecto }}\right.$ and $\left.k_{\mathrm{RPM}}\right)$ of soil carbon pools were calibrated in this study, and not the mechanisms that mimic the effect of temperature and moisture on decomposition.

Finally, because the effect of some soil properties (e.g., $\mathrm{CaCO}_{3}$ content, $\mathrm{pH}$ ) on OC cycle is not incorporated in SoilGen2 (except clay and water content), the difference of these properties in two regions may explain part of the variation in calibrated parameters. This relationship could be quantified via regression analysis based on many simulated and calibrated plots. However, the small number of calibrated plots in our study does not allow for such analysis.

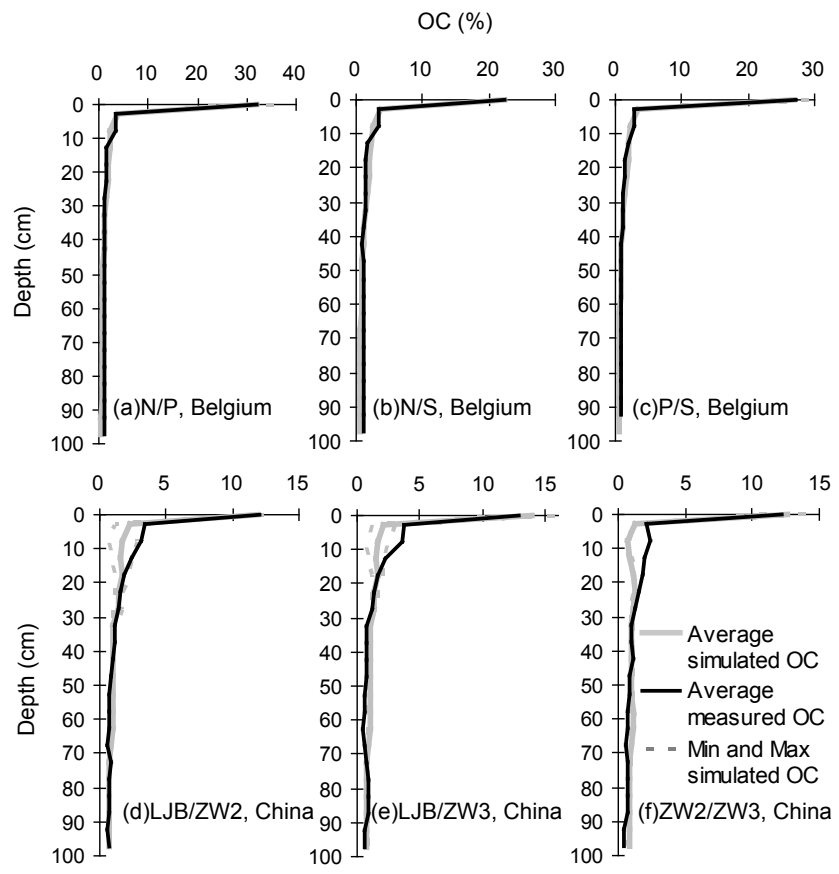

Fig. 5. Comparison of vertical distribution of simulated vs. measured OC content in soil pedons. (a) N/P pedons in Belgium; (b) $\mathrm{N} / \mathrm{S}$ pedons in Belgium; (c) $\mathrm{P} / \mathrm{S}$ pedons in Belgium; (d) LJB/ZW2 pedons in China; (e) LJB/ZW3 pedons in China; (f) ZW2/ZW3 pedons in China. Min is minimal value while Max is maximal value.

In addition, the different calibrated results in Belgium and China indicate that future calibrations are needed for distinct climate conditions, possibly for different soil types as well, and uncertainty bandwidths of calibrated parameters should be given. The current study however does not allow a certain statement on this topic as only a few soil type/climate combinations have been explored.

\section{Conclusions}

Sensitivity analysis based on the Morris method shows that $k_{\mathrm{HUM}}, \mathrm{fr}_{\text {ecto }}$ and $k_{\mathrm{RPM}}$ are the three most important parameters in SoilGen 2 to affect change of OC both in Belgian and Chinese soil pedons. The sensitivity orders of the parameters follow the same pattern in the two regions, but the values of elementary effects differ.

According to the results of sensitivity analysis, SoilGen2 parameters are calibrated by decreasing $k_{\mathrm{HUM}}, \mathrm{fr}_{\mathrm{ecto}}$ and $k_{\mathrm{RPM}}$. The final results are obtained by the following combination of parameters: $k_{\mathrm{HUM}}=0.0065-0.0074, k_{\mathrm{RPM}}=0.27-$ 0.27 and $\mathrm{fr}_{\text {ecto }}=0.30-0.38$ in Belgium and $k_{\mathrm{HUM}}=0.016$ $0.019, k_{\mathrm{RPM}}=0.30-0.30$ and $\mathrm{fr}_{\text {ecto }}=0.37-0.43$ in China. The less significant sensitivity of parameters in the sensitivity analysis and larger variation of parameters during calibration in Belgium compared to China may be attributed to their distinct vegetation types and climate conditions. 


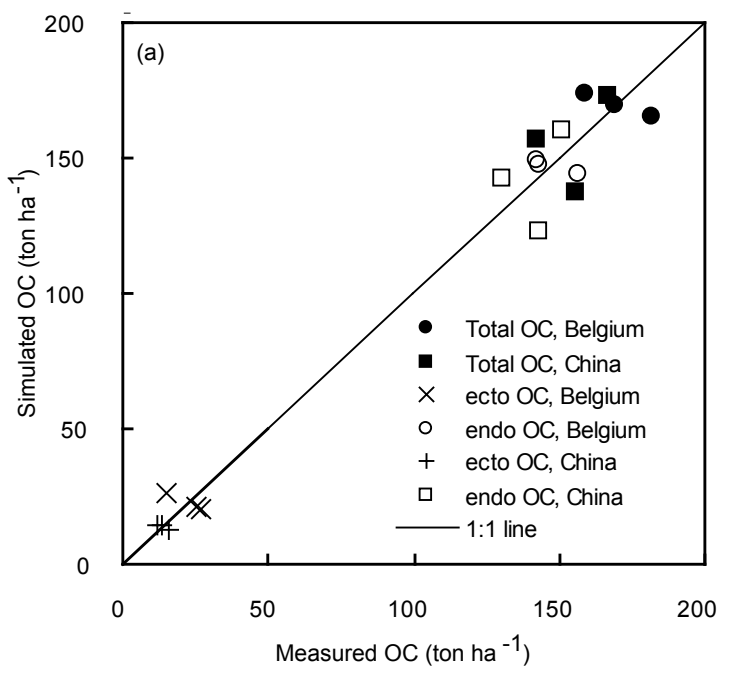

$\mathrm{OC}(\%)$

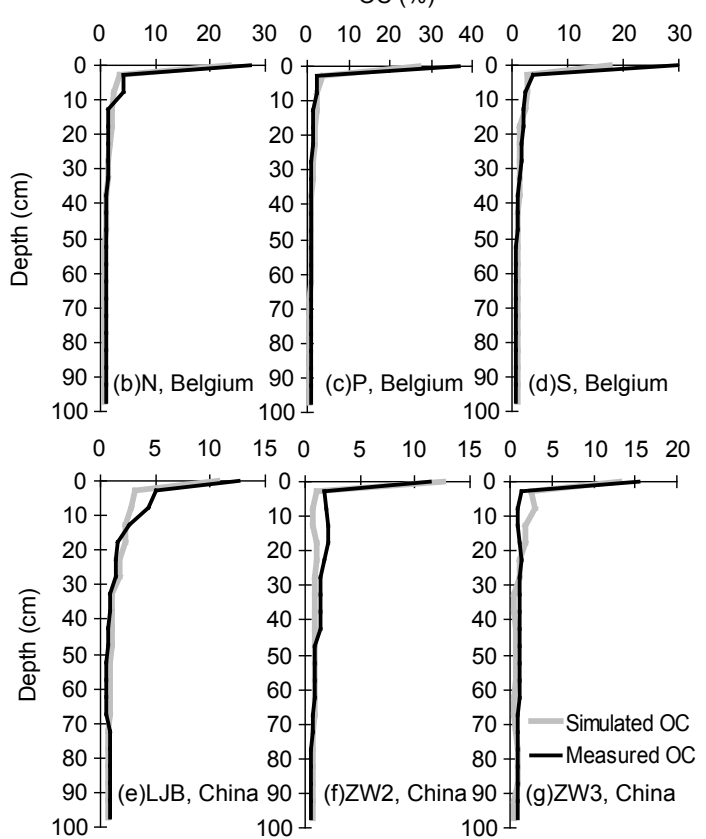

Fig. 6. Comparison of measured and simulated OC based on soil pedons for validation in Belgium and China. (a) OC mass in Belgium and China; (b) OC content of $\mathrm{N}$ pedon in Belgium; (c) $\mathrm{OC}$ content of $\mathrm{P}$ pedon in Belgium; (d) $\mathrm{OC}$ content of $\mathrm{S}$ pedon in Belgium; (e) OC content of LJB pedon in China; (f) OC content of ZW2 pedon in China; (g) OC content of ZW3 pedon in China.

The calibrated parameters follow the law that OC in deeper soil layers is more resistant to decomposition than in surface soil layers, which is induced by the age of carbon and an unfavorable environment for soil micro-organisms in the deeper layers. This indicates that the calibration allows better simulation of carbon storage in the whole soil pedon. The calibrated SoilGen 2 will be the base for quantitative soil carbon pool reconstruction based on the application of it to loess-soil sequences deposited in China in future studies, which will offer an opportunity to understand the mechanism of carbon cycle at geological timescale.

Acknowledgements. This work was supported by the CAS Strategic Priority Research Program Grant No. XDA05120000, the National Natural Science Foundation of China (No: 41102222, 41071055) and LiSUM project of Erasmus Mundus External Cooperation Window. Thanks are extended to Arne Verstraeten and Nathalie Cools of the Research Institute for Nature and Forest, Belgium, for the measured data of litter input in Sonian Forest region.

Edited by: D. Lawrence

\section{References}

Berg, B. and McClaugherty, C. (Eds.): Plant Litter: decomposition, humus formation, carbon Sequestration, 2nd Edn., SpringerVerlag, Berlin-Heidelberg, Germany, 2008.

Campolongo, F., Kleijnen, J., and Andres, T.: Screening methods, in: Sensitivity analysis, edited by: Saltelli, A., Chan, K., and Scott, M., Wiley and Sons, Chichester, UK, 65-80, 2000.

Cao, Y., Zhao, Z., Qu, M., Cheng, X. Y., and Wang D. H.: Effects of Robinia pseudoacacia roots on deep soil moisture status, Chin. J. Appl. Ecol., 17, 765-768, 2006.

Coldwell, B. B. and DeLong, W. A.: Studies of the composition of deciduous forest tree leaves before and after partial decomposition, Sci. Agric., 30, 456-466, 1950.

Coleman, K. and Jenkinson, D. S.: RothC-26.3 a model for the turnover of carbon in soil, available at: http://www. rothamsted.bbsrc.ac.uk/aen/carbon/download.htm (last access: 10 June 2012), 2005.

Coleman, K., Jenkinson, D. S., Crocker, G. J., Grace, P. R., Klír, J., Körschens, M., Poulton, P. R., and Richter D. D.: Simulating trends in soil organic carbon in long-term experiments using RothC-26.3, Geoderma, 81, 29-44, 1997.

Cui, L. J., Liang, Z. S., Han, R. L., and Yang, J. W.: Biomass soil and root system distribution characteristics of Seabuckthorn $x$ Poplar mixed forest, Sci. Silv. Sin., 39, 1-7, 2003.

Davis, B. A. S., Brewer, S., Stevenson, A. C., Guiot, J., and Data Contributors: The temperature of Europe during the Holocene reconstructed from pollen data, Quaternary Sci. Rev., 22, 17011716, 2003.

De Wit, H. A., Palosuo, T., Hylen, G., and Liski, J.: A carbon budget of forest biomass and soils in southeast Norway, Forest Ecol. Manag., 225, 15-26, 2006.

Doherty, J. (Ed.): PEST: model independent parameter estimation user manual, Fifth Edition, Watermark Numerical Computing, Brisbane, Australia, 2004.

Falkowski, P., Scholes, R. J., Boyle, E., Canadell, J., Canfield, D., Elser, J., Gruber, N., Hibbard, K., Högberg, P., Linder, S., Mackenzie, F. T., Moore III, B., Pedersen, T., Rosenthal, Y., Seitzinger, S., Smetacek, V., and Steffen, W.: The global carbon cycle: a test of our knowledge of earth as a system, Science, 290, 291-296, 2000.

Finke, P. A.: Modeling the genesis of Luvisols as a function of topographic position in loess parent material, Quaternary Int., 265, 3-17, 2012. 
Finke, P. A. and Hutson, J.: Modelling soil genesis in calcareous loess, Geoderma, 145, 462-479, 2008.

Gobat, J. M., Aragno, M., and Matthey, W. (Eds): The Living Soil: Fundamentals of Soil Science and Soil Biology, Science Publishers Inc., NH, USA, 2004.

Gong, Z. T., Chen, Z. C., and Zhang, G. L.: World reference base for soil resources (WRB): Establishment and development, Soils, 35, 271-278, 2003.

Gower, J. C.: A general coefficient of similarity and some of its properties, Biometrics, 27, 623-637, 1971.

Grievank, A. and Walter, A. (Eds.): Evaluating derivatives, principles and techniques of algorithmic differentiation, SIAM, Philadelphia, USA, 2008.

Guo, Z. T., Ruddiman, W. F., Hao, Q. Z., Wu, H. B., Qiao, Y. S., Zhu, R. X., Peng, S. Z., Wei, J. J., Yuan, B. Y., and Liu, T. S.: Onset of Asian desertification by $22 \mathrm{Myr}$ ago inferred from loess deposits in China, Nature, 416, 159-163, 2002.

Hu, X. N., Zhao, Z., Yuan, Z. F., Li, J., Guo, M. C., and Wang, D. H.: A model for fine root growth of Robinia pseudoacacia in the Loess Plateau, Sci. Silv. Sin., 46, 126-132, 2010.

IUSS Working Group WRB: World Reference Base for Soil Resources 2006, in: World Soil Resources Report No. 103, 2nd Edn., FAO, Rome, Italy, 2006.

Jenkinson, D. S.: The turnover of organic carbon and nitrogen in soil, Philos. T. R. Soc. Lond., 329, 361-368, 1990.

Jenkinson, D. S. and Coleman, K.: Calculating the annual input of organic matter to soil from measurements of total organic carbon and radiocarbon, Eur. J. Soil Sci., 45, 167-174, 1994.

Jenny, H.: Derivation of state factor equations of soils and ecosystems, Soil Sci. Soc. Am. Pro., 25, 385-388, 1961.

Jensen, L. S., Mueller, T., Nielsen, N. E., Hansen, S., Crocker, G. J., Grace, P. R., Klir, J., Korschens, M., and Poulton, P. R.: Simulating trends in soil organic carbon in long-term experiments using the soil-plant-atmosphere model DAISY, Geoderma, 81, 5-28, 1997.

Kelly, R. H., Parton W. J., Crocker, G. J., Graced, P. R., Klir, J., Korschens, M., Poulton, P. R., and Richter, D. D.: Simulating trends in soil organic carbon in long-term experiments using the century model, Geoderma, 81, 75-90, 1997.

Kirkby, M. J.: Soil development models as a component of slope models, Earth Surf. Proc. Landf., 2, 203-230, 1977.

Kononova, M. M.: Humus of virgin and cultivated soils, in: Soil components. I. Organic Components, edited by: Gieseling, J. E., Springer, Berlin, Germany, 475-526, 1975.

Kukla, G. J.: Correlation of Chinese, European and American loess series with deep-sea sediments, in: Aspects of loess research, edited by: Liu, T. S., China Ocean Press, Beijing, China, 27-38, 1987.

Lal, R.: Soil Carbon sequestration impacts on global climate change and food security, Science, 304, 1623-1627, 2004.

Lambers, H., Chapin, F. S., and Pons, T. L. (Eds.): Plant Physiological Ecology, Springer-Verlag New York Inc, New York, USA, 1998.

Langohr, R. and Sanders, J.: The Belgian loess belt in the last 20,000 years: evolution of soils and relief in the Zoniën forest, in: Soils and Quaternary Landscape Evolution, edited by: Boardman, J., Wiley, Chichester, UK, 359-371, 1985.

Li, C. S., Frolking, S., Crocker, G. J., Grace, P. R., Klir, J., Korchens, M., and Poulton, P. R.: Simulating trends in soil organic carbon in long-term experiments using the DNDC model, Geoderma, 81, 45-60, 1997.

Liu, T. S. (Ed.): Loess and the Environment, Science Press, Beijing, China, 1985.

Liu, Y.: The relationship between community biomass and soil moisture, soil nutrient in ZIwuling typical forests, Master Degree thesis, Northwest Agriculture and Forest University, Yangling, China, 2007.

Mermut, A. R., Amundson, R., and Cerling, T. E.: The use of stable isotopes in studying carbonate dynamics in soils, in: Global Climate Change and Pedogenic Carbonates, edited by: Lal, R., Kimble, J. M., Eswaran, H., and Stewart, B. A. (Eds), CRC Press, Boca Raton, USA, 65-85, 2000.

Minasny, B. and McBratney, A. B.: A rudimentary mechanistic model for soil production and landscape development, Geoderma, 90, 3-21, 1999.

Minasny, B. and McBratney, A. B.: A rudimentary mechanistic model for soil production and landscape development II. A twodimensional model incorporating chemical weathering, Geoderma, 103, 161-179, 2001.

Minasny, B., McBratney, A. B., and Salvador-Blanes, S.: Quantitative models for pedogenesis: a review, Geoderma, 144, 140-157, 2008.

Morris, M. D.: Factorial sampling plans for preliminary computational experiments, Technometrics, 33, 161-174, 1991.

Oakley, J. and O'Hagan, A.: Probabilistic sensitivity analysis of complex models: a Bayesian approach, J. Roy. Stat. Soc. B., 66, 751-769, 2004.

Parton, W. J., Schimel, D. S., Cole, C. V., and Ojima, D. S.: Analysis of factors controlling soil organic matter levels in Great Plains grasslands, Soil Sci. Soc. Am. J., 51, 1173-1179, 1987.

Paul, K. I. and Polglase, P. J.: Calibration of the RothC model to turnover of soil carbon under eucalypts and pines, Aust. J. Soil Res., 42, 883-895, 2004.

Paul, K. I., Polglase, P. J., and Richards, G. P.: Sensitivity analysis of predicted change in soil carbon following afforestation, Ecol. Model., 164, 137-152, 2003.

Post, W. F., Peng, T. H., Emanuel, W. R., King, A. W., Dale, V. H., and DeAngelis, D. L.: The global carbon cycle, Am. Sci., 78, 310-326, 1990.

Quideau, S. A., Chadwick, O. A., Benesi, A., Graham, R. C., and Anderson, M. A.: A direct link between forest vegetation type and soil organic matter composition, Geoderma, 104, 41-60, 2001.

Raich, J. W. and Tufekcioglu, A.: Vegetation and soil respiration: correlations and controls, Biogeochemistry, 48, 71-90, 2000.

Saltelli, A., Chan, K., and Scott, M. (Eds.): Sensitivity analysis, Wiley and Sons, Chichester, UK, 2000.

Saltelli, A., Ratto, M., Tarantola, S., and Campolongo, F.: Sensitivity analysis for chemical models, Chem. Rev., 105, 2811-2827, 2005.

Salvador-Blanes, S., Minasny, B., and McBratney, A. B.: Modelling long-term in situ soil profile evolution: application to the genesis of soil profiles containing stone layers, Eur. J. Soil Sci., 58, 15351548, 2007.

Sauer, D., Finke, P. A., Sørensen, R., Sperstad, R., Schülli-Maurer, I., Høeg, H., and Stahr, K.: Testing a soil development model against southern Norway soil chronosequences, Quaternary. Int., 265, 18-31, 2012. 
Schimel, D. S., Braswell, B. H., Holland, E. A., McKeown, R., Ojima, D. S., Painter, T. H., Parton, W. J., and Townsend, A. R.: Climatic, edaphic, and biotic controls over storage and turnover of carbon in soils, Global Biogeochem. Cy., 8, 279-293, 1994.

Schlesinger, W. H. and Andrews, J. A.: Soil respiration and the global carbon cycle, Biogeochemistry, 48, 7-20, 2000.

Shirato, Y., Hakamata, T., and Taniyama, I.: Modified Rothamsted carbon model for Andosols and its validation: changing humus decomposition rate constant with pyrophosphate-extractable Al, Soil Sci. Plant Nutr., 50, 149-158, 2004.

Skjemstad, J. O., Spouncer, L. R., Cowie, B., and Swift, R. S.: Calibration of the Rothamsted organic carbon turnover model (RothC ver.26.3), using measurable soil organic carbon pools, Aust. J. Soil Res., 42, 79-88, 2004.

Swift, R. S.: Sequestration of carbon by soil, Soil Sci., 166, 858871, doi:10.1097/00010694-200111000-00010, 2001.

Todorovic, G. R., Stemmer, M., Tatzber, M., Katzlberger, C., Spiegel, H., Zehetner, F., and Gerzabek, M. H.: Soil-carbon turnover under different crop management: evaluation of RothCmodel predictions under Pannonian climate conditions, J. Plant Nutr. Soil Sci., 173, 662-670, 2010.
Van Ranst, E.: Vorming and eigenschappen van lemige bosgronden in midden en hoog België, Ph.D. thesis, Ghent University, Ghent, Belgium, 1981.

Verbruggen, C., Denys, L., and Kiden, P.: Belgium, in: Palaeoecological Events During the Last 15000 Years. Regional Syntheses of Palaeoecological Studies of Lakes and Mires in Europe, edited by: Berglund, B. E., Birks, H. J. B., Ralska-Jasiewiczowa, M., Wright, H. E., Wiley, Chichester, 1996.

Vrugt, J. A., Braak C. J. F., Diks, C. G. H., Robinson, B. A., Hyman, J. M., and Higdon, D.: Accelerating Markov Chain Monte Carlo simulation by differential evolution with self-adaptive randomized subspace sampling, Int. J. Nonlin. Sci. Num., 10, 273-290, 2009.

Zhang, D. Q., Hui, D. F., Luo, Y. Q., and Zhou, G. Y.: Rates of litter decomposition in terrestrial ecosystems: global pattern and controlling factors, J. Plant Ecol., 1, 85-93, 2008.

Zhang, J., Wang, Y. K., and Wu, Q. X.: Comparison of litterfall and its process between some forest types in Loess Plateau, J. Soil Water Conserv., 15, 91-94, 2001.

Zhang, X. B. and Shangguan, Z. P.: The bio-cycle patterns of nutrient elements and stand biomass in forest communities in Hilly Loess Regions, Acta Ecol. Sin., 25, 527-537, 2005. 